\title{
ॠUSGS
}

Prepared in cooperation with the

New York State Department of Environmental Conservation

\section{Groundwater Quality in the Chemung River Basin, New York, 2008}

Open-File Report 2011-1112

U.S. Department of the Interior

U.S. Geological Survey 
Cover. Coleman Avenue, near Harris Hill, Town of Big Flats, Chemung County. 


\section{Groundwater Quality in the Chemung River Basin, New York, 2008}

By Amy J. Risen and James E. Reddy

Prepared in cooperation with the

New York State Department of Environmental Conservation

Open-File Report 2011-1112 


\title{
U.S. Department of the Interior \\ KEN SALAZAR, Secretary \\ U.S. Geological Survey \\ Marcia K. McNutt, Director
}

\section{U.S. Geological Survey, Reston, Virginia: 2011}

\author{
For more information on the USGS — the Federal source for science about the Earth, its natural and living resources, \\ natural hazards, and the environment, visit http://www.usgs.gov or call 1-888-ASK-USGS \\ For an overview of USGS information products, including maps, imagery, and publications, \\ visit http://www.usgs.gov/pubprod \\ To order this and other USGS information products, visit http://store.usgs.gov
}

\begin{abstract}
Any use of trade, product, or firm names is for descriptive purposes only and does not imply endorsement by the U.S. Government.

Although this report is in the public domain, permission must be secured from the individual copyright owners to reproduce any copyrighted materials contained within this report.
\end{abstract}

Suggested citation:

Risen, A.J., and Reddy, J.E., 2011, Groundwater quality in the Chemung River Basin, New York, 2008: U.S. Geological Survey Open-File Report 2011-1112, 25 p., at http://pubs.usgs.gov/of/2011/1112. 


\section{Contents}

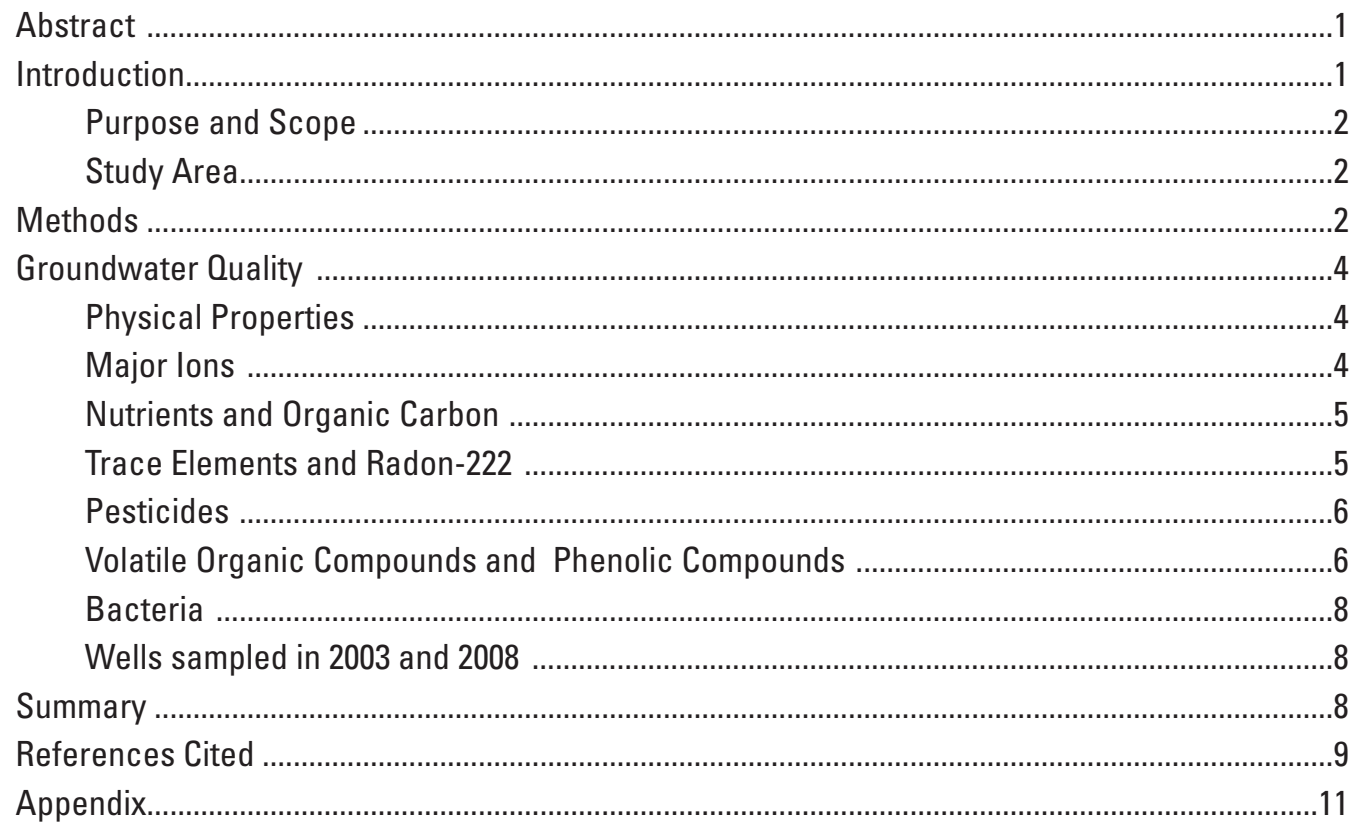

\section{Figure}

1. Map showing pertinent geographic features of study area in the Chemung River Basin, New York, and locations of the 10 wells sampled in 2008

\section{Tables}

1. Summary statistics for concentrations of major ions in sand and gravel aquifers and bedrock aquifers in the Chemung River Basin, New York, 2008

2. Summary statistics for concentrations of nutrients and organic carbon in sand and gravel aquifers and bedrock aquifers in the Chemung River Basin, New York, 2008.

3. Summary statistics for concentrations of trace elements and radon-222 in sand and gravel aquifers and bedrock aquifers in the Chemung River Basin, New York, 2008 
Conversion Factors, Datum, and Acronyms

\begin{tabular}{lcl}
\hline Multiply & By & To obtain \\
\hline & Length & \\
\hline inch (in.) & 2.54 & centimeter $(\mathrm{cm})$ \\
foot (ft) & 0.3048 & meter $(\mathrm{m})$ \\
\hline & Area & \\
\hline square mile $\left(\mathrm{mi}^{2}\right)$ & 2.590 & square kilometer $\left(\mathrm{km}^{2}\right)$ \\
\hline & Flow rate & \\
\hline million gallons per day $(\mathrm{Mgal} / \mathrm{d})$ & 0.04381 & cubic meter per second $\left(\mathrm{m}^{3} / \mathrm{s}\right)$ \\
\hline
\end{tabular}

Temperature in degrees Celsius $\left({ }^{\circ} \mathrm{C}\right)$ may be converted to degrees Fahrenheit $\left({ }^{\circ} \mathrm{F}\right)$ as follows:

$$
{ }^{\circ} \mathrm{F}=\left(1.8 \mathrm{x}^{\circ} \mathrm{C}\right)+32
$$

Vertical coordinate information is referenced to North American Vertical Datum of 1929

(NAVD 29).

Horizontal coordinate information is referenced to the North American Datum of 1983 (NAD 83).

\section{List of Acronyms}

$\begin{array}{ll}\text { AL } & \text { Action Level } \\ \text { AMCL } & \text { Alternative maximum contaminant level } \\ \text { CFU/mL } & \text { Colony forming units per milliliter } \\ \text { CIAT } & \text { 2-Chloro-4-isopropylamino-6-amino-s-triazine (also called deethylatrazine) } \\ \text { DWA } & \text { Drinking Water Advisory } \\ \text { ESA } & \text { Ethanesulfonic acid } \\ \text { HPC } & \text { Heterotrophic plate count } \\ \text { LRL } & \text { Laboratory Reporting Level } \\ \text { MCL } & \text { Maximum Contaminant Level } \\ \text { MTBE } & \text { Methyl-tert-butyl ether } \\ \mu \text { g/L } & \text { micrograms per liter } \\ \mu m & \text { micrometer } \\ \mu S / c m & \text { microsiemens per centimeter at 25 degrees Celsius } \\ \text { mg/L } & \text { milligrams per liter } \\ \text { NWOL } & \text { USGS National Water Quality Laboratory } \\ \text { NYSDEC } & \text { New York State Department of Environmental Conservation } \\ \text { NYSDOH } & \text { New York State Department of Health } \\ \text { OA } & \text { Oxanilic acid } \\ \text { OGRL } & \text { USGS Organic Geochemistry Research Laboratory } \\ \text { OIET } & \text { 2-Hydroxy-4-isopropylamino-6-ethylamino-s-triazine (also called hydroxyatrazine) } \\ \text { pCi/L } & \text { picocuries per liter } \\ \text { Pt-Co units } & \text { Platinum-cobalt units } \\ \text { SMCL } & \text { Secondary Maximum Contaminant Level } \\ \text { USEPA } & \text { U.S. Environmental Protection Agency } \\ \text { USGS } & \text { U.S. Geological Survey } \\ \text { VOC } & \text { Volatile organic compound } \\ \end{array}$




\title{
Groundwater Quality in the Chemung River Basin, New York, 2008
}

\author{
By Amy J. Risen and James E. Reddy
}

\section{Abstract}

The second groundwater quality study of the Chemung River Basin in south-central New York was conducted as part of the U.S. Geological Survey 305(b) water-qualitymonitoring program. Water samples were collected from five production wells and five private residential wells from October through December 2008. The samples were analyzed to characterize the chemical quality of the groundwater. Five of the wells are screened in sand and gravel aquifers, and five are finished in bedrock aquifers. Two of these wells were also sampled for the first Chemung River Basin study of 2003. Samples were analyzed for 6 physical properties and 217 constituents, including nutrients, major inorganic ions, trace elements, radionuclides, pesticides, volatile organic compounds, phenolic compounds, organic carbon, and four types of bacterial analyses. Results of the water-quality analyses for individual wells are presented in tables, and summary statistics for specific constituents are presented by aquifer type. The results are compared with Federal and New York State drinking-water standards, which typically are identical.

Water quality in the study area is generally good, but concentrations of some constituents equaled or exceeded current or proposed Federal or New York State drinkingwater standards; these were: sodium (one sample), total dissolved solids (one sample), aluminum (one sample), iron (one sample), manganese (four samples), radon-222 (eight samples), trichloroethene (one sample), and bacteria (four samples). The $\mathrm{pH}$ of all samples was typically neutral or slightly basic (median 7.5); the median water temperature was 11.0 degrees Celsius $\left({ }^{\circ} \mathrm{C}\right)$. The ions with the highest median concentrations were bicarbonate (median 202 milligrams per liter $[\mathrm{mg} / \mathrm{L}]$ ) and calcium (median $59.0 \mathrm{mg} / \mathrm{L}$ ). Groundwater in the study area is moderately hard to very hard, but more samples were hard or very hard $(121 \mathrm{mg} / \mathrm{L}$ as calcium carbonate $\left(\mathrm{CaCO}_{3}\right)$ or greater $)$ than were moderately hard (61-120 mg/L as $\mathrm{CaCO}_{3}$ ); the median hardness was $205 \mathrm{mg} / \mathrm{L}$ as $\mathrm{CaCO}_{3}$. The maximum concentration of nitrate plus nitrite was $3.67 \mathrm{mg} / \mathrm{L}$ as nitrogen, which did not exceed established drinking-water standards for nitrate plus nitrite $(10 \mathrm{mg} / \mathrm{L}$ as nitrogen). The trace elements with the highest median concentrations were strontium (median 196.5 micrograms per liter $[\mu \mathrm{g} / \mathrm{L}]$ ), barium (median $186 \mu \mathrm{g} / \mathrm{L}$ ), and iron (median $72.5 \mu \mathrm{g} / \mathrm{L}$ in unfiltered water). Five pesticides and pesticide degradates were detected among four samples at concentrations of $0.11 \mu \mathrm{g} / \mathrm{L}$ or less; they included herbicides and herbicide degradates. Six volatile organic compounds (VOCs) were detected among four samples; these included four solvents, methyl tert-butyl ether, and one trihalomethane. Trichloroethene, a solvent, was detected in one production well at $5.5 \mu \mathrm{g} / \mathrm{L}$; the Federal and New York State Maximum Contaminant Level (MCL) (5 $\mathrm{g} / \mathrm{L})$ was exceeded. The highest radon-222 activities were in samples from bedrock wells [maximum 1,740 picocuries per liter ( $\mathrm{pCi} / \mathrm{L})$ ]; eight of the wells sampled exceeded a proposed U.S. Environmental Protection Agency (USEPA) drinking-water standard of $300 \mathrm{pCi} / \mathrm{L}$. Any detection of coliform bacteria indicates a potential violation of New York State health regulations; total coliform bacteria were detected in four samples, and fecal coliform bacteria were detected in one sample.

\section{Introduction}

Section 305(b) of the Federal Clean Water Act Amendments of 1977 requires that states monitor and report biennially on the chemical quality of surface water and groundwater within their boundaries (U.S. Environmental Protection Agency, 1997). In 2002, the U.S. Geological Survey (USGS), in cooperation with the New York State Department of Environmental Conservation (NYSDEC), developed a program to evaluate groundwater quality throughout the major river basins in New York on a rotating basis. The work parallels the NYSDEC Rotating Intensive Basin Study program, which evaluates surface-water quality in 2 or 3 of the 14 major river basins in the State each year. The groundwater-quality program began in 2002 with a pilot study in the Mohawk River Basin (Butch and others, 2003). Groundwater-quality sampling was completed in the Chemung River Basin in 2003 (Hetcher-Aguila, 2004); the Lake Champlain (Nystrom, 2006) and Susquehanna River Basins in 2004 (Hetcher-Aguila and Eckhardt, 2006); the St. Lawrence (Nystrom, 2007b), Delaware (Nystrom, 2007a), and 
Genesee River Basins (Eckhardt and others, 2007) in 2005; the Mohawk River Basin (Nystrom, 2008) and western New York (Niagara and Allegheny River Basins, and tributaries to Lake Erie and western Lake Ontario) (Eckhardt and others, 2008) in 2006; and the Upper Hudson River Basin (Nystrom, 2009) and Central New York (Oswego, Seneca, and Oneida River Basins) (Eckhardt and others, 2009) in 2007. Sampling in the Eastern Lake Ontario Basin, the Chemung River Basin, and the Lower Hudson River Basin (Nystrom, 2010) was completed in 2008 .

\section{Purpose and Scope}

This report presents the results of the 2008 groundwater study in the Chemung River Basin in south-central New York. It supplements the water-quality study completed in 2003 in the Chemung River Basin (Hetcher-Aguila, 2004) by re-sampling two of the wells from that study (wells SB 1470 and SB 2326) and provides analytical results for eight new wells (fig. 1). This report briefly describes the study area and the sampling methods, and presents results of the 2008 waterquality analyses. Summary statistics (number of samples exceeding Federal or State drinking-water standards) and the minimum, median, and maximum concentrations of selected analytes in 10 samples from wells in surficial and bedrock aquifers are given in tables 1 to 3 . Information on the sampled wells and detailed analytical results for all analytes are given in Appendix tables 1-1 through 1-9 at the end of the report.

\section{Study Area}

The Chemung River Basin (1,744-square miles [ $\left.\left.\mathrm{mi}^{2}\right]\right)$ lies mostly in south-central New York and partly in northcentral Pennsylvania (fig. 1). A complete description of the study area is presented in the first Chemung River Basin report (Hetcher-Aguila, 2004). Briefly, the study area includes all or parts of seven counties in south-central New York. It encompasses the Cohocton River Basin and the Canisteo River Basin. The main valley of the Chemung River trends northwest-southeast, is about 1 mile wide in most places, and empties into the Susquehanna River, south of Waverly, New York, in Pennsylvania. The entire study area lies within the Appalachian Plateau physiographic province. The Chemung River valley is filled with as much as 500 feet of glaciofluvial sand and gravel and glaciolacustrine silt and clay (Miller, 1982). Saturated deposits of sand and gravel form aquifers that supply water to the villages and cities throughout the basin, including the cities of Elmira, Corning, and Bath (fig. 1). The main valley intersects northeast-southwest trending glaciated tributary valleys that are also filled with glacial sediments. Bedrock aquifers are used for water supply where sand and gravel aquifers are absent, typically in upland areas. The bedrock uplands rise as high as $900 \mathrm{ft}$ above the valley floor and consist of nearly flat-lying interbedded shales, siltstones, and fine-grained sandstones of Devonian age.

\section{Methods}

A total of 10 wells were selected for sample collection as described by Hetcher-Aguila (2004). Five are finished in sand and gravel aquifers, and five are finished in bedrock aquifers. The five wells that tap sand and gravel are production wells, and the five bedrock wells are private residential wells. Sampling was done from October through December 2008. The water samples were analyzed for 6 physical properties and 217 constituents, including 4 types of bacterial analyses. Three samples - two field blanks and one replicate sample - were collected for quality assurance (QA) and quality control (QC), as required for the Federal 305(b) program.

Samples were collected from every well for these analyses and were processed by methods described in USGS manuals for the collection of water-quality data (U.S. Geological Survey, variously dated). A detailed description of the sampling and analytical methods is given by HetcherAguila (2004). Samples collected for pesticide analyses were processed by the methods of Shelton (1994), Sandstrom and others (2001), and Wilde and others (2004). These samples were analyzed for 132 pesticides and pesticide degradates through methods described by Zaugg and others (1995), Furlong and others (2001), Sandstrom and others (2001), Meyer and others (1993), and Lee and Strahan (2003). The analytical method devised by Zaugg and others (1995) was developed in cooperation with the U.S. Environmental Protection Agency (USEPA) and allows detection of the Nation's most commonly used pesticides. Samples for bacterial analyses were processed in accordance with New York State Department of Health (NYSDOH) guidelines.

The analyses for physical properties, most trace elements and metals, acid-neutralizing capacity, organic carbon, radon222 , volatile organic compounds (VOCs), and phenols were done on unfiltered water samples to obtain total whole-water concentrations. Dissolved concentrations of nutrients, major inorganic constituents, three metals, and pesticides were obtained from filtered samples. Concentrations of iron and manganese were measured in both filtered and unfiltered samples to provide the total and dissolved concentrations (table 1-6). Sulfuric acid was added to the samples collected for phenol analysis. Hydrochloric acid was added to samples collected for total organic carbon, VOC, and mercury analyses, and nitric acid was added to some of the samples collected for trace-element analyses to prevent sample degradation. Samples collected for dissolved inorganiccompound analyses were filtered through a 0.45 -micrometer $(\mu \mathrm{m})$ cellulose capsule filter that was attached to the Teflon discharge line inside the sample-collection chamber; samples for pesticide analysis were filtered through a $0.7-\mu \mathrm{m}$ furnacebaked glass-fiber plate filter using the methods of Wilde and others (2004).

The samples were stored on ice in coolers and delivered directly or shipped by overnight delivery to four laboratories: (1) the USGS National Water Quality Laboratory (NWQL) 


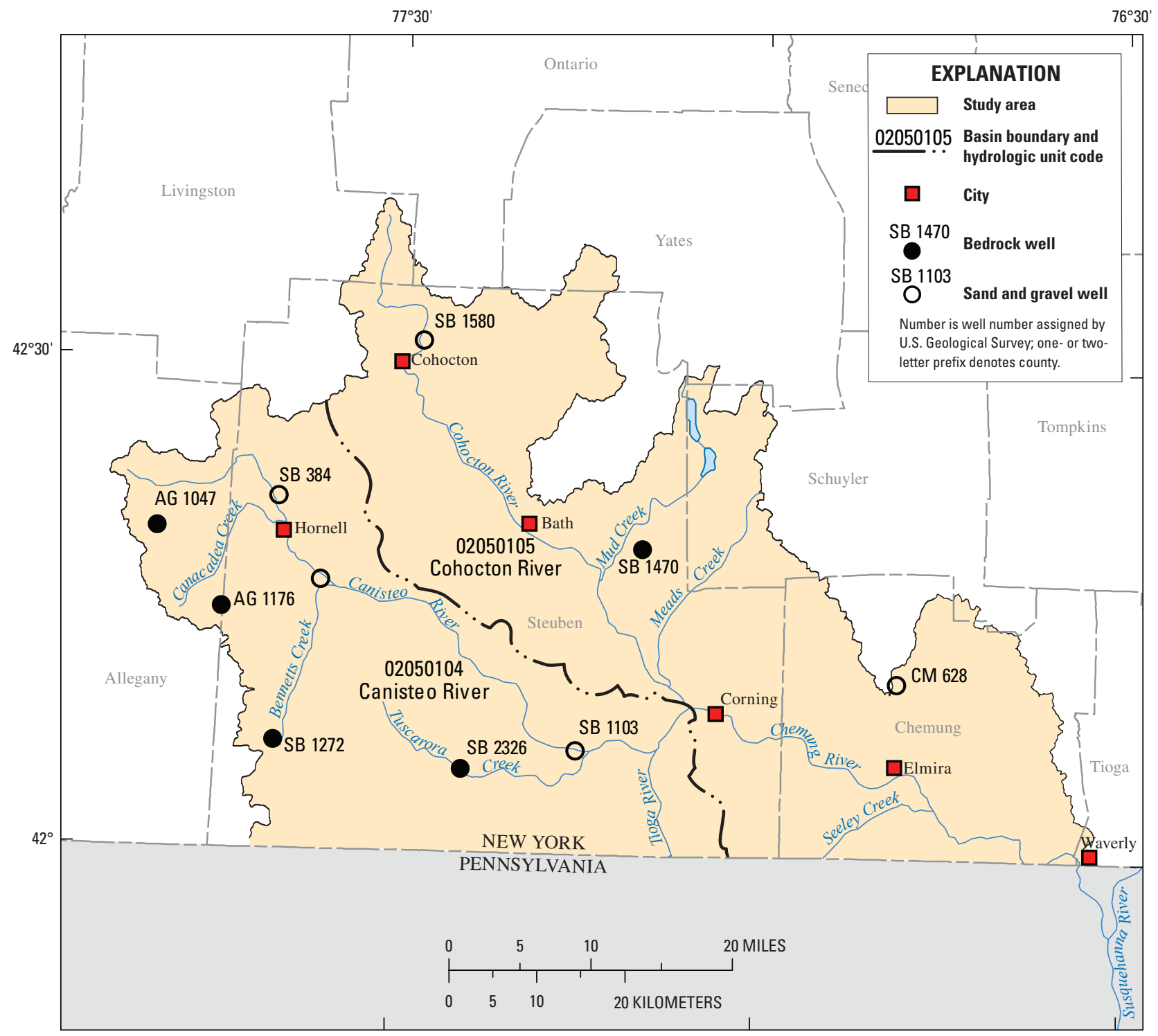

Base from U.S. Geological Survey, Seamless Data Distribution System, accessed in 2009

at http://seamless.usgs.gov

Universal Transverse Mercator projection, Zone 18

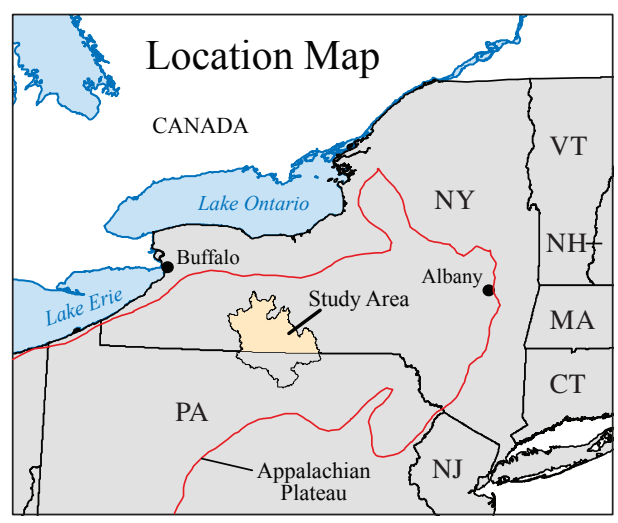

Figure 1. Pertinent geographic features of study area in the Chemung River Basin, New York, and locations of the 10 wells sampled in 2008. (Well data are given in table 1-1 at end of report.) 
in Denver, Colorado, for analysis for inorganic major ions, nutrients, inorganic trace elements and radon-222, VOCs, and some pesticides; (2) the USGS Organic Geochemistry Research Laboratory (OGRL) in Lawrence, Kansas, for additional pesticides; (3) a NYSDOH-certified laboratory in Melville, N.Y., for total organic carbon and phenolic compounds; and (4) a NYSDOH-certified laboratory in Ithaca, N.Y., for bacterial analysis.

\section{Groundwater Quality}

Samples from 10 wells were analyzed for 223 constituents and physical properties. More than one-half (163) of these were not detected above the laboratory reporting levels (LRLs) in any sample (table 1-2). Results for the remaining 60 constituents and properties that were detected are presented in the appendix. The categories are as follows: physical properties (table 1-3), inorganic constituents (table 1-4), nutrients and total organic carbon (table 1-5), trace elements and radon-222 (table 1-6), pesticides (table 1-7), VOCs table 1-8), and bacterial water-quality indicators (table 1-9). Some concentrations were reported as "estimated" when the detected value was less than the established LRL, or when recovery of a compound has been shown to be highly variable (Childress and others, 1999).

Analytical results for selected constituents were compared with Federal and New York State drinking-water standards, which typically are identical. The standards include Maximum Contaminant Levels (MCLs), Secondary Maximum Contaminant Levels (SMCLs), Drinking Water Advisories (DWAs), and Action Levels (ALs) established by the USEPA (2002, 2004, and 2009) and the New York State Department. of Health (2007a). MCLs are enforceable standards that specify the highest level of a contaminant that is allowed in public drinking-water supplies; they are not enforceable for private homeowner wells but are presented here as a standard for evaluation of the results. SMCLs are non-enforceable guidelines based on cosmetic and aesthetic criteria, such as taste and odor. DWAs are non-enforceable guidelines for concentrations of contaminants that are not likely to have adverse health or aesthetic effects. ALs require water systems to use treatment techniques for the reduction of contaminants; for example, concentrations of metals could be reduced by controlling corrosiveness. There are several additional compounds for which detections must be reported by public-water systems in their annual report (New York State Department of Health, 2007a;b).

The QA/QC field blank contained no constituent in concentrations greater than the LRLs, except toluene, which was detected at a trace concentration of $0.2 \mu \mathrm{g} / \mathrm{L}$, and silica, which was detected at 0.14 milligrams per liter $(\mathrm{mg} / \mathrm{L})$; this indicates that little to no contamination occurred through the sampling or analytical procedures. The results of analysis of the $\mathrm{QA} / \mathrm{QC}$ replicate sample indicate that variability in sample results meets the precision requirements of the study. The analytes with the largest percent differences between concentrations in a groundwater sample and that in the replicate sample were acid-neutralizing capacity, residue on evaporation, and low-concentration trace elements (concentrations near the LRL for the trace elements).

The quality of the sampled groundwater was generally acceptable, although at each well the concentrations of some constituents exceeded Federal or New York State drinkingwater standards. Exceedances generally involved minerals that occur from natural interactions of water and rock (aluminum, iron, manganese, sodium) but also include the anthropogenic contaminants chloroform and trichloroethene, as well as bacterial contaminants. Eight of the wells tested exceeded the USEPA proposed MCL for radon-222, which is generated from the natural decay of uranium.

\section{Physical Properties}

The $\mathrm{pH}$ of the samples (table 1-3) ranged from 7.0 to 7.7; the median was $\mathrm{pH} 7.6$ for sand and gravel wells and $\mathrm{pH} 7.5$ for bedrock wells. The temperature of the water ranged from 8.6 to $15.1^{\circ} \mathrm{C}$; the median was $11.0^{\circ} \mathrm{C}$ for sand and gravel wells and $11.6^{\circ} \mathrm{C}$ for bedrock wells. Specific conductance of the samples ranged from 277 to $1,080 \mu \mathrm{S} / \mathrm{cm}$ at $25^{\circ} \mathrm{C}$; the median was $498^{\circ} \mu \mathrm{S} / \mathrm{cm}$ at $25^{\circ} \mathrm{C}$ for sand and gravel wells and $538 \mu \mathrm{S} / \mathrm{cm}$ at $25^{\circ} \mathrm{C}$ for bedrock wells. Dissolved-oxygen concentrations ranged from less than $0.1 \mathrm{mg} / \mathrm{L}$ (the LRL) to $5.4 \mathrm{mg} / \mathrm{L}$ : the median was $0.6 \mathrm{mg} / \mathrm{L}$ for sand and gravel wells and $2.8 \mathrm{mg} / \mathrm{L}$ for bedrock wells. The color of the samples ranges from less than 1 platinum-cobalt (Pt-Co) unit to 8 Pt-Co units; the median was 5 Pt-Co units for sand and gravel wells and $5 \mathrm{Pt}$-Co units for bedrock wells. The odor of hydrogen sulfide gas, which may occur in the absence of oxygen, was noted by field personnel in water from one of the bedrock wells.

\section{Major lons}

The anions that were detected in the highest concentrations were bicarbonate (alkalinity), chloride, and sulfate (tables 1 and 1-4). Bicarbonate concentrations ranged from 129 to $531 \mathrm{mg} / \mathrm{L}$ as $\mathrm{CaCO}_{3}$; the median was $187 \mathrm{mg} / \mathrm{L}$ for sand and gravel wells and $217 \mathrm{mg} / \mathrm{L}$ for bedrock wells. Chloride concentrations ranged from 0.72 to $99.1 \mathrm{mg} / \mathrm{L}$; the median was $49.2 \mathrm{mg} / \mathrm{L}$ for sand and gravel wells and $9.27 \mathrm{mg} / \mathrm{L}$ for bedrock wells. Sulfate concentrations ranged from 7.81 to $49.5 \mathrm{mg} / \mathrm{L}$; the median was $23.3 \mathrm{mg} / \mathrm{L}$ for sand and gravel wells and $28.3 \mathrm{mg} / \mathrm{L}$ for bedrock wells.

The cations that were detected in the highest concentrations were calcium, magnesium, and sodium (tables 1 and 1-4). Calcium concentrations ranged from 29.8 to $108 \mathrm{mg} / \mathrm{L}$; the median was $65.3 \mathrm{mg} / \mathrm{L}$ for sand and gravel wells and $40.3 \mathrm{mg} / \mathrm{L}$ for bedrock wells. Magnesium concentrations ranged from 8.01 to $29.4 \mathrm{mg} / \mathrm{L}$; the median 
Table 1. Summary statistics for concentrations of major ions in sand and gravel aquifers and bedrock aquifers in the Chemung River Basin, New York, 2008.

[Concentrations are in milligrams per liter (mg/L). All samples represent filtered water; --, not applicable; E, estimated; $\mathrm{CaCO}_{3}$, calcium carbonate]

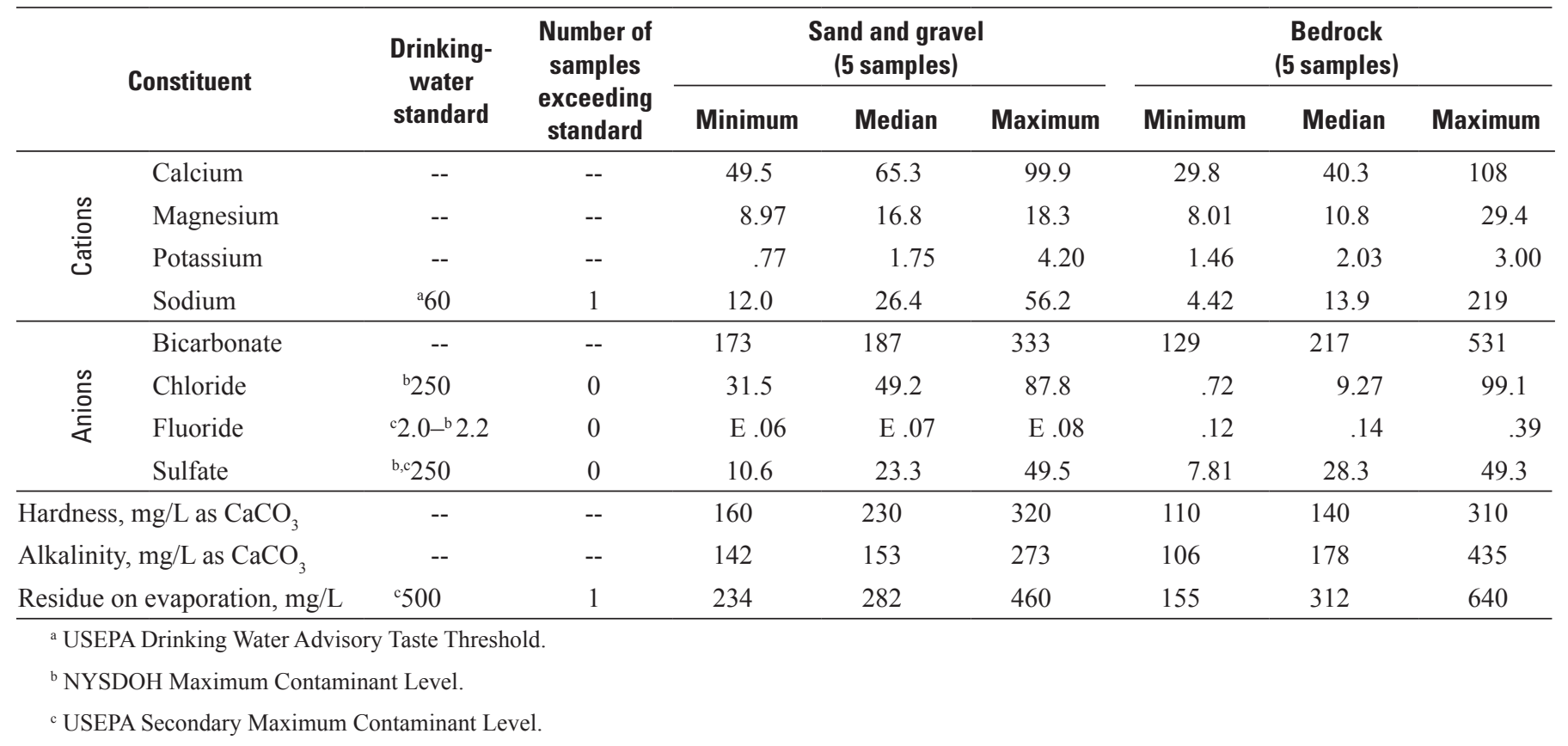

was $16.8 \mathrm{mg} / \mathrm{L}$ for sand and gravel wells and $10.8 \mathrm{mg} / \mathrm{L}$ for bedrock wells. Sodium concentrations ranged from 4.42 to $219 \mathrm{mg} / \mathrm{L}$; the median was $26.4 \mathrm{mg} / \mathrm{L}$ for sand and gravel wells and $13.9 \mathrm{mg} / \mathrm{L}$ for bedrock wells. One bedrock well sample exceeded the USEPA nonregulatory drinking-water advisory taste threshold, which recommends that sodium concentrations in drinking water not exceed the range of 30 to 60 mg/L (U.S. Environmental Protection Agency, 2002; 2009).

Calcium and magnesium contribute to water hardness. Water hardness in the basin ranged from 110 to $320 \mathrm{mg} / \mathrm{L}$ as $\mathrm{CaCO}_{3}$; the median was $230 \mathrm{mg} / \mathrm{L}$ for sand and gravel wells and $140 \mathrm{mg} / \mathrm{L}$ for bedrock wells. One well yielded water that was moderately hard (61-120 mg/L as $\mathrm{CaCO}_{3}$ ); and five wells yielded water that was very hard (greater than $180 \mathrm{mg} / \mathrm{L}$ as $\left.\mathrm{CaCO}_{3}\right)(\mathrm{Hem}, 1985)$. Wells finished in bedrock were slightly more alkaline (median $178 \mathrm{mg} / \mathrm{L}$ as $\mathrm{CaCO}_{3}$ ) than those finished in sand and gravel (median $153 \mathrm{mg} / \mathrm{L}$ as $\mathrm{CaCO}_{3}$ ). Residue on evaporation is a measure of total dissolved solids, and ranged from 155 to $640 \mathrm{mg} / \mathrm{L}$. The median residue on evaporation was $282 \mathrm{mg} / \mathrm{L}$ for sand and gravel wells and $312 \mathrm{mg} / \mathrm{L}$ for bedrock wells; one bedrock sample exceeded the USEPA SMCL of $500 \mathrm{mg} / \mathrm{L}$.

\section{Nutrients and Organic Carbon}

Nitrate and ammonia were the predominant nutrients in the ground-water samples (tables 2 and 1-5); nitrite and organic nitrogen concentrations were negligible in most samples. Nitrate plus nitrite concentrations ranged from less than 0.04 (the LRL) to $3.67 \mathrm{mg} / \mathrm{L}$ as nitrogen $(\mathrm{N})$; the median concentration was $1.21 \mathrm{mg} / \mathrm{L}$ in samples from sand and gravel wells and $0.05 \mathrm{mg} / \mathrm{L}$ in samples from bedrock wells. Ammonia concentrations ranged from less than 0.02 (the LRL) to $0.596 \mathrm{mg} / \mathrm{L}$ as $\mathrm{N}$. Concentrations of orthophosphate were typically low; the maximum concentration was $0.103 \mathrm{mg} / \mathrm{L}$ (as phosphorus). Total organic carbon concentrations ranged from an estimated $0.4 \mathrm{mg} / \mathrm{L}$ to $2.2 \mathrm{mg} / \mathrm{L}$.

\section{Trace Elements and Radon-222}

The elements detected in the highest concentrations were aluminum, barium, boron, iron, lithium, manganese, and strontium (table 3). Aluminum, boron, lithium, and strontium were generally present at higher concentrations in bedrock wells than at concentrations in sand and gravel wells. Aluminum concentrations ranged from less than 6 (the $\mathrm{LRL})$ to $69 \mu \mathrm{g} / \mathrm{L}$; the SMCL $(50 \mu \mathrm{g} / \mathrm{L})$ was exceeded in one bedrock well sample. Barium concentrations ranged from 38.8 to $937 \mu \mathrm{g} / \mathrm{L}$. Boron concentrations ranged from 9.4 to $372 \mu \mathrm{g} / \mathrm{L}$; MCLs have not been established for boron. Iron concentrations in filtered samples ranged from less than $4 \mu \mathrm{g} / \mathrm{L}$ (the LRL) to $503 \mu \mathrm{g} / \mathrm{L}$; the Federal SMCL and the New York State MCL for iron $(300 \mu \mathrm{g} / \mathrm{L})$ were exceeded in one sand and gravel well sample. Lithium concentrations ranged from 1.5 to $104 \mu \mathrm{g} / \mathrm{L}$; MCLs have not been established for lithium. Manganese concentrations in filtered samples ranged from less 
Table 2. Summary statistics for concentrations of nutrients and organic carbon in sand and gravel aquifers and bedrock aquifers in the Chemung River Basin, New York, 2008.

[All samples represent filtered water except as noted; mg/L, milligrams per liter; --, not applicable; <, less than; N, nitrogen; P, phosphorus; E, estimated]

\begin{tabular}{|c|c|c|c|c|c|c|c|c|}
\hline \multirow{2}{*}{ Constituent } & \multirow{2}{*}{$\begin{array}{l}\text { Drinking- } \\
\text { water } \\
\text { standard }\end{array}$} & \multirow{2}{*}{$\begin{array}{l}\text { Number of } \\
\text { samples } \\
\text { exceeding } \\
\text { standard }\end{array}$} & \multicolumn{3}{|c|}{$\begin{array}{l}\text { Sand and gravel } \\
\text { (5 samples) }\end{array}$} & \multicolumn{3}{|c|}{$\begin{array}{l}\text { Bedrock } \\
\text { (5 samples) }\end{array}$} \\
\hline & & & Minimum & Median & Maximum & Minimum & Median & Maximum \\
\hline Ammonia plus organic $\mathrm{N}, \mathrm{mg} / \mathrm{L}$ as $\mathrm{N}$ & -- & -- & E.06 & $<.10$ & .18 & $<.10$ & .13 & .65 \\
\hline Ammonia, $\mathrm{mg} / \mathrm{L}$ as $\mathrm{N}$ & -- & -- & $<.020$ & $<.020$ & .123 & $<.020$ & $<.020$ & .596 \\
\hline Nitrite plus nitrate, $\mathrm{mg} / \mathrm{L}$ as $\mathrm{N}$ & $\mathrm{a}, \mathrm{b} 10$ & 0 & $<.04$ & 1.21 & 2.29 & $<.04$ & .05 & 3.67 \\
\hline Nitrite, $\mathrm{mg} / \mathrm{L}$ as $\mathrm{N}$ & $\mathrm{a}, \mathrm{b} 1$ & 0 & $<.002$ & $<.002$ & .044 & $<.002$ & $<.002$ & $<.002$ \\
\hline Orthophosphate, $\mathrm{mg} / \mathrm{L}$ as $\mathrm{P}$ & -- & -- & E.005 & $<.008$ & .103 & E.005 & E.006 & E.007 \\
\hline Total organic carbon, unfiltered, mg/L & -- & -- & E.4 & 1.0 & 1.1 & E. 5 & 1.5 & 2.2 \\
\hline
\end{tabular}

${ }^{a}$ USEPA Maximum Contaminant Level.

${ }^{\mathrm{b}}$ NYSDOH Maximum Contaminant Level.

than $0.2 \mu \mathrm{g} / \mathrm{L}$ (the LRL) to $198^{\circ} \mu \mathrm{g} / \mathrm{L}$; the Federal SMCL for manganese $(50 \mu \mathrm{g} / \mathrm{L})$ was exceeded in three sand and gravel well samples. Strontium concentrations ranged from 50.1 to $638 \mu \mathrm{g} / \mathrm{L} ;$ MCLs have not been established for strontium.

Radon-222 was detected in every sample (table 1-6), and activity ranged from 153 to $1,740 \mathrm{pCi} / \mathrm{L}$. The median activity was $450 \mathrm{pCi} / \mathrm{L}$ in samples from sand and gravel wells and $1,430 \mathrm{pCi} / \mathrm{L}$ in samples from bedrock wells. The proposed MCL of $300 \mathrm{pCi} / \mathrm{L}$ for radon-222 in drinking water was exceeded in eight samples, but the proposed Alternate Maximum Contaminant Level (ACML) of 4,000 pCi/L was not exceeded. The AMCL is the proposed allowable activity of radon in raw-water samples where the State has implemented mitigation programs to address the health risks of radon in indoor air. The proposed MCL and AMCL for radon are under review and have not been adopted (U.S. Environmental Protection Agency, 2004; 2006).

Some trace elements were detected less frequently or at lower concentrations (table 3 ) than other constituents. The MCLs for antimony $(6 \mu \mathrm{g} / \mathrm{L})$, arsenic $(10 \mu \mathrm{g} / \mathrm{L})$, beryllium $(4 \mu \mathrm{g} / \mathrm{L})$, cadmium $(5 \mu \mathrm{g} / \mathrm{L})$, chromium $(100 \mu \mathrm{g} / \mathrm{L})$, selenium $(50 \mu \mathrm{g} / \mathrm{L})$, silver $(100 \mu \mathrm{g} / \mathrm{L})$, thallium $(2 \mu \mathrm{g} / \mathrm{L})$, zinc $(5,000 \mu \mathrm{g} / \mathrm{L})$, and uranium $(30 \mu \mathrm{g} / \mathrm{L})$, and the SMCL for copper $(1,000 \mu \mathrm{g} / \mathrm{L})$, were not exceeded in any sample. Cobalt and nickel were detected, but no MCLs have been established for them. Antimony, beryllium, cadmium, mercury, silver, and thallium were not detected in any sample (table 1-2).

\section{Pesticides}

Five pesticides and related compounds (including four pesticide degradates) were detected in water from four wells (table 1-7). All of the samples containing pesticides were from sand and gravel aquifers. Caffeine is not a pesticide; however, it is measured as part of the pesticide analyses because it can be an indicator of human wastes. Caffeine was not detected in any sample (table 1-2). The herbicide atrazine and two of its degradates - CIAT (2-chloro-4-isopropylamino-6-aminos-triazine, also called deethylatrazine) and OIET (2-hydroxy4-isopropylamino-6-ethylamino-s-triazine, also called hydroxytriazine) - were detected. Atrazine was detected in a sample from one production well at an estimated concentration of $0.002 \mu \mathrm{g} / \mathrm{L}$. CIAT was detected in three samples at estimated concentrations ranging from 0.002 to $0.009 \mu \mathrm{g} / \mathrm{L}$, and OIET was detected in one sample at an estimated $0.007 \mu \mathrm{g} / \mathrm{L}$. Alachlor ESA, a degradate of the herbicide alachlor, was detected in samples from two production wells at 0.02 and $0.03 \mu \mathrm{g} / \mathrm{L}$. Metolachlor ESA, a degradate of the herbicide metolachlor, was detected in three samples at a range of 0.06 to $0.11 \mu \mathrm{g} / \mathrm{L}$, and these are the highest concentrations measured for any pesticide-related product in this study. No pesticide concentration exceeded Federal or New York State MCLs, and no Federal MCLs currently have been established for these pesticide degradation products. However, NYSDOH requires that any detections of alachlor ESA or atrazine in public water supplies be reported in their annual reports. These trace-level detections of pesticides are similar to those reported by Eckhardt and others (2001), Phillips and others (1999), and Eckhardt and Stackelberg (1995) from studies of pesticides in groundwater throughout New York State.

\section{Volatile Organic Compounds and Phenolic Compounds}

Volatile Organic Compounds and Phenolic Compounds Six VOCs were detected in four samples; two samples were from sand and gravel wells, and two were from 
Table 3. Summary statistics for concentrations of trace elements and radon-222 in sand and gravel aquifers and bedrock aquifers in the Chemung River Basin, New York, 2008.

[All concentrations are in micrograms per liter except as noted. All samples unfiltered except as noted. pCi/L, picocuries per liter; --, not applicable; E, estimated; $<$, less than]

\begin{tabular}{|c|c|c|c|c|c|c|c|c|}
\hline \multirow{2}{*}{ Constituent } & \multirow{2}{*}{$\begin{array}{l}\text { Drinking- } \\
\text { water } \\
\text { standard }\end{array}$} & \multirow{2}{*}{$\begin{array}{l}\text { Number of } \\
\text { samples } \\
\text { exceeding } \\
\text { standard }\end{array}$} & \multicolumn{3}{|c|}{$\begin{array}{l}\text { Sand and gravel } \\
\text { (5 samples) }\end{array}$} & \multicolumn{3}{|c|}{$\begin{array}{c}\text { Bedrock } \\
\text { (5 samples) }\end{array}$} \\
\hline & & & Minimum & Median & Maximum & Minimum & Median & Maximum \\
\hline Aluminum & '50 & 1 & $<6$ & $<6$ & $<6$ & $<6$ & 25 & 69 \\
\hline Antimony & a,b 6 & 0 & $<.4$ & $<.4$ & $<.4$ & $<.4$ & $<.4$ & $<.4$ \\
\hline Arsenic & ${ }^{\mathrm{a}} 10$ & 0 & E.18 & .23 & 7.5 & E.16 & .21 & .30 \\
\hline Barium & $\mathrm{a}, \mathrm{b} 2,000$ & 0 & 89.5 & 267 & 937 & 38.8 & 146 & 411 \\
\hline Beryllium & $\mathrm{a}, \mathrm{b} 4$ & 0 & $<.02$ & $<.02$ & $<.02$ & $<.02$ & $<.02$ & $<.02$ \\
\hline Boron, filtered & -- & -- & 9.4 & 16 & 38 & 18 & 29 & 372 \\
\hline Chromium & ${ }^{a, b} 100$ & 0 & $<.40$ & $<.40$ & $<.40$ & E. 21 & $<.40$ & $<.40$ \\
\hline Cobalt & -- & -- & E.06 & $<.10$ & $<.10$ & E.08 & $<.10$ & .16 \\
\hline Copper & ${ }^{\mathrm{c}} 1,000$ & 0 & E 2.2 & $<4.0$ & 4.2 & E 2.3 & $<4.0$ & 11.8 \\
\hline Iron, filtered & $\mathrm{b}, \mathrm{c} 300$ & 1 & $<4$ & 15 & 503 & E 3 & E 4 & 76 \\
\hline Iron & $\mathrm{b}, \mathrm{c} 300$ & 1 & $<14$ & 16 & 507 & E 9 & 40 & 126 \\
\hline Lead & $\mathrm{d} 15$ & 0 & $<.10$ & .42 & 1.15 & .14 & .22 & 1.36 \\
\hline Lithium & -- & -- & 1.5 & 6.3 & 15 & 10.4 & 12.3 & 104 \\
\hline Manganese, filtered & ${ }^{\mathrm{c}} 50--^{\mathrm{b}} 300$ & ${ }^{\mathrm{c}} 3-{ }^{\mathrm{b}} 0$ & $<.2$ & 57.5 & 198 & .3 & 3.2 & 33.5 \\
\hline Manganese & ${ }^{\mathrm{c}} 50-\mathrm{b} 300$ & ${ }^{\mathrm{c}} 4-{ }^{\mathrm{b}} 0$ & 1.1 & 58.3 & 230 & 5.1 & 10.1 & 75.1 \\
\hline Molybdenum & -- & -- & .1 & .3 & 1.0 & $<.1$ & .2 & .8 \\
\hline Nickel & -- & -- & E.17 & .29 & .50 & E.11 & .26 & .48 \\
\hline Selenium & $\mathrm{a}, \mathrm{b} 50$ & 0 & E.07 & $<.12$ & .21 & $<.12$ & $<.12$ & .15 \\
\hline Silver & ${ }^{a, b} 100$ & 0 & $<.06$ & $<.06$ & $<.06$ & $<.06$ & $<.06$ & $<.06$ \\
\hline Strontium & -- & -- & 110 & 118 & 199 & 50.1 & 227 & 63 \\
\hline Thallium & -- & -- & $<.12$ & $<.12$ & $<.12$ & $<.12$ & $<.12$ & $<.12$ \\
\hline Zinc & $\mathrm{b}, \mathrm{c} 5,000$ & 0 & E 1.6 & 2.2 & 12.4 & 2.4 & 5.1 & 24.6 \\
\hline Radon-222, pCi/L & $\mathrm{e} 300$ & 8 & 290 & 450 & 600 & 153 & 1,430 & 1,740 \\
\hline Uranium & a30 & 0 & .025 & .237 & .620 & $<.020$ & .456 & 1.64 \\
\hline
\end{tabular}

bedrock wells (table 1-8). MTBE, tetrachloroethene, trichloroethene, 1,1,1-trichloroethane, and trichloromethane (also called chloroform) were detected at concentrations ranging from 0.1 to $5.7 \mu \mathrm{g} / \mathrm{L}$ in samples from two production wells. MTBE is a gasoline additive that can infiltrate into groundwater from leaking fuel tanks. Chloroform is a member of a group of compounds called trihalomethanes. Trihalomethanes are typically formed as by-products when chlorine or bromine is used to disinfect water. The State and
Federal MCL of $80 \mu \mathrm{g} / \mathrm{L}$ for total trihalomethanes was not exceeded. Trichloroethene was detected in one production well at $5.5 \mu \mathrm{g} / \mathrm{L}$; the Federal and New York State MCL $(5 \mu \mathrm{g} / \mathrm{L})$ was exceeded. The New York State MCLs for 1,1,1-trichloroethane, tetrachloroethene, and toluene $(5 \mu \mathrm{g} / \mathrm{L})$ were not exceeded. Chloroform and toluene were also detected in two residential wells, each at $0.2 \mu \mathrm{g} / \mathrm{L}$. Phenolic compounds, which are semivolatile, were not detected in any sample (table 1-2). 


\section{Bacteria}

All samples were analyzed for total coliform, fecal coliform, Escherichia coli (E. coli), and heterotrophic bacteria. Coliform bacteria were detected in four samples, and fecal coliforms were detected in one sample; E. coli were not detected (table 1-9). Coliform bacteria were detected in one sample from a sand and gravel production well and in three samples from private supply bedrock wells. The NYSDOH and USEPA MCL violation for total coliform bacteria occurs when 5 percent of samples of finished water collected in one month test positive for total coliform (if 40 or more samples are collected per month) or when two samples are positive for total coliform (if fewer than 40 samples are collected per month). Heterotrophic plate counts (HPCs) ranged from less than 1 (absent) to 403 colony-forming units per milliliter (CFU/mL).

\section{Wells sampled in 2003 and 2008}

Two of the wells sampled in the fall of 2008 were sampled previously in the summer of 2003 as part of this study; one is bedrock residential well SB 1470, and the other is sand and gravel production well CM 628. Of the 223 constituents and physical properties analyzed for in 2008, 52 were common to the 2003 and 2008 analyses (tables 1-10 through 1-13). Most of the 2008 measurements changed less than 25 percent from the 2003 measurements, and those that changed more than 50 percent are reported below. Water quality was generally good, and the constituents that exceeded State or Federal MCLs or SMCLs at these wells were aluminum and bacteria.

The physical properties changed less than 11 percent, with exception to water color, which increased by at least 100 percent for both wells (table 1-10). The major ions changed less than 20 percent (table 1-10). Concentrations of most major nutrients and organic carbon changed less than 30 percent, although nitrate plus nitrite decreased 60 percent and total organic carbon increased 83 percent for well SB1470 (table 1-10). No MCLs were exceeded for physical properties, major ions, major nutrients, or organic carbon. The trace element and radon-222 concentrations (table 1-11) in 2003 and 2008 were also very similar; however, concentrations of several constituents changed by more than 50 percentaluminum, cobalt, iron, manganese, nickel, and zinc for well SB 1470 and manganese and nickel for well CM 628. Radon222 concentrations for both wells and both years exceeded the proposed Federal MCL of $300 \mathrm{pCi} / \mathrm{L}$, but the proposed AMCL of $4,000 \mathrm{pCi} / \mathrm{L}$ was not exceeded. Pesticide concentrations (table 1-12) were similar; no pesticides were detected in samples for well SB 1470 in either year, but both atrazine and its degradate CIAT were detected at concentrations in the low nanograms for well CM 628 in both years (OIET was not measured in 2003). Atrazine concentrations were low, and the 2008 concentration for well CM 628 was an estimated
$0.008 \mu \mathrm{g} / \mathrm{L}$, a 27 percent decrease from 2003. No VOCs or phenolics were detected in either well for either year (table 1-13). Bacterial analyses (table 1-10) were positive for coliform for both years at both wells, and the positive results exceed the State MCL. Both wells tested positive for E. coli in 2003, exceeding the State MCL; however, no E. coli were detected in either well in 2008. HPCs increased 168 percent in the sample from well SB 1470 in 2008.

\section{Summary}

In 2001, the U.S. Geological Survey, in cooperation with the New York State Department of Environmental Conservation, began an assessment of groundwater quality in bedrock and sand and gravel aquifers throughout New York State. As a part of this assessment, the Chemung River Basin was studied in 2003 and again in 2008. The 2008 study is the subject of this report. For the 2008 study, 10 water samples were collected from five production wells and five private residential wells from October through December 2008. Water samples were analyzed for 223 physical properties and constituents, including inorganic major ions, nutrients, organic carbon, trace elements, radon-222, pesticides, volatile organic compounds (VOCs), phenolic compounds, and bacteria. Two wells, CM 628 and SB 1470, were tested in both studies and a comparison was made of the results. The measurements for most constituents changed little; measurements of only eight constituents changed more than 50 percent from the 2003 value.

The quality of the sampled groundwater was generally acceptable in 2003 and 2008. However, each well sampled in 2008 had at least one constituent that exceeded a Federal or New York State drinking-water standard, or goal, or proposed standard. Maximum Contaminant Levels (MCLs) or Secondary Maximum Contaminant Levels set by the U.S. Environmental Protection Agency (USEPA) and New York State Department of Health for trace elements (manganese, iron, and (or) aluminum) were exceeded in samples from five wells, for the bacterial analyses (total and (or) fecal coliform) at four wells, for the volatile organic compound trichloroethene at one well, and for residue on evaporation at one well. The USEPA drinking-water advisory taste threshold was exceeded for one inorganic ion (sodium) at one well. The USEPA proposed MCL for the radioactive isotope radon-222 was exceeded at eight wells. Five pesticides and related compounds (including four pesticide degradates) were detected in water from four production wells. No pesticide concentration exceeded Federal or New York State MCLs, and no Federal MCLs currently have been established for these pesticide degradation products. Six VOCs were detected in four samples; two samples were from production wells, and two were from private residential wells. Trichloroethene was detected in one production well at $5.5 \mu \mathrm{g} / \mathrm{L}$; the Federal and New York State MCL $(5 \mu \mathrm{g} / \mathrm{L})$ was exceeded. 


\section{References Cited}

Butch, G.K., Murray, P.M., Hebert, G.J., and Weigel, J.F., 2003, Water resources data, New York, water year 2002: U.S. Geological Survey Water-Data Report NY-02-1, p. 502-520.

Childress, C.J.O., Foreman, W.T., Connor, B.F., and Maloney, T.J., 1999, New reporting procedures based on long-term method detection levels and some considerations for interpretations of water-quality data provided by the U.S. Geological Survey National Water Quality Laboratory: U.S. Geological Survey Open-File Report 99-193, 19 p.

Eckhardt, D.A., Hetcher, K.K., Phillips, P.J., and Miller, T.S., 2001, Pesticides and their metabolites in community water-supply wells of central and western New York, August 1999: U.S. Geological Survey Water-Resources Investigations Report 00-4128, $12 \mathrm{p}$.

Eckhardt, D.A., Reddy, J.E., and Shaw, S.B., 2009, Groundwater quality in central New York, 2007: U.S. Geological Survey Open-File Report 2009-1257, 40 p., at http://pubs.usgs.gov/of/2009/1257/.

Eckhardt, D.A., Reddy, J.E., and Tamulonis, K.L., 2007, Groundwater quality in the Genesee River Basin, New York, 2005-06: U.S. Geological Survey Open-File Report 2007-1093, 26 p., at http://pubs.usgs.gov/of/2007/1093/.

Eckhardt, D.A., Reddy, J.E., and Tamulonis, K.L., 2008, Groundwater quality in western New York, 2007: U.S. Geological Survey Open-File Report 2008-1140, 36 p., at http://pubs.usgs.gov/of/2008/1140/.

Eckhardt, D.A. and Stackelberg, P.E., 1995, Relation of ground-water quality to land use of Long Island, New York: Ground Water, v. 33, no. 6, p. 1019-1033.

Furlong, E.T., Anderson, B.D., Werner, S.L., Soliven, P.P., Coffey, L.J., and Burkhardt, M.R., 2001, Methods of analysis by the U.S. Geological Survey National Water Quality Laboratory---Determination of pesticides in water by graphitized carbon-based solid-phase extraction and high-performance liquid chromatography/mass spectrometry: U.S. Geological Survey Water-Resources Investigations Report 01-4134, 73 p.

Hem, J.D., 1985, Study and interpretation of the chemical characteristics of natural water ( $3 \mathrm{~d}$ ed.): U.S. Geological Survey Water-Supply Paper 2254, 264 p.

Hetcher-Aguila, K.K., 2004, Groundwater quality in the Chemung River Basin, New York, 2003: U.S. Geological Survey Open-File Report 04-1329, 19 p., at http://ny.water. usgs.gov/pubs/of/of041329/.

Hetcher-Aguila, K.K., and Eckhardt, D.A., 2006, Groundwater quality in the upper Susquehanna River basin, New York, 2004-05: U.S. Geological Survey Open-File Report 06-1161, 20 p., http://pubs.usgs.gov/of/2006/1161/.
Lee, E.A. and Strahan, A.P., 2003, Determination of acetamide herbicides and their degradation products in water using online solid-phase extraction and liquid chromatography/ mass spectrometry: U.S. Geological Survey Open-File Report 03-173, $17 \mathrm{p}$.

Meyer, M.T., Mills, M.S., and Thurman, E.M., 1993, Automated solid-phase extraction of herbicides from water for gas chromatographic-mass spectrometric analysis: Journal of Chromatography, v. 629, p. 55-59.

Miller, T.S., 1982, Elmira-Horseheads-Big Flats area, in Waller, R.M., and Finch, A.J., eds., Atlas of eleven selected aquifers in New York: U.S. Geological Survey Open-File Report 82-553, p. 127-147.

New York State Department of Health, 2007a, Public water systems - Maximum Contaminant Levels: Troy, N.Y., Bureau of Public Water Supply Protection, accessed January 2009, at http://www health.state.ny.us/nysdoh/water/part5/ tables.htm.

New York State Department of Health, 2007b, Public water systems - Codes, Rules, and Regulations: Troy, N.Y., Bureau of Public Water Supply Protection, accessed October 2007, at http://www health.state ny.us/ environmental/water/drinking/part5/subpart5 htm.

Nystrom, E.A., 2006, Groundwater quality in the Lake Champlain Basin, New York, 2004: U.S. Geological Survey Open-File Report 2006-1088, 22 p., at http://pubs. usgs.gov/of/2006/1088/.

Nystrom, E.A., 2007a, Groundwater quality in the Delaware River Basin, New York, 2001 and 2005-2006: U.S. Geological Survey Open-File Report 2007-1098, 36 p., at . http://pubs.usgs.gov/of/2007/1098/.

Nystrom, E.A., 2007b, Groundwater quality in the St. Lawrence River Basin, New York, 2005-06: U.S. Geological Survey Open-File Report 2007-1066, 33 p., at http://pubs.usgs.gov/of/2007/1066/.

Nystrom, E.A., 2008, Groundwater quality in the Mohawk River Basin, New York, 2006: U.S. Geological Survey Open-File Report 2008-1086, 33 p., at http://pubs.usgs.gov/ of $/ 2008 / 1086 /$.

Nystrom, E.A., 2009, Ground-water quality in the Upper Hudson River Basin, New York, 2007: U.S. Geological Survey Open-File Report 2009-1240, 37 p., at http://pubs. usgs.gov/of/2009/1240/.

Nystrom, E.A., 2010, Groundwater quality in the Lower Hudson River Basin, New York, 2008: U.S. Geological Survey Open-File Report 2010-1197, 39 p., at http://pubs. usgs.gov/of/2010/1197/. 
Phillips, P.J., Eckhardt, D.A., Terracciano, S.A., and Rosenmann, L.R., 1999, Pesticides and their metabolites in wells of Suffolk County, New York, 1998: U.S. Geological Survey Water-Resources Investigations Report 99-4095, $12 \mathrm{p}$.

Sandstrom, M.W., Stroppel, M.E., Foreman, W.T., and Schroeder, M.P., 2001, Methods of analysis by the U.S. Geological Survey National Water Quality LaboratoryDetermination of moderate-use pesticides and selected degradates in water by $\mathrm{C}-18$ solid-phase extraction and gas chromatography/mass spectrometry: U.S. Geological Survey Water-Resources Investigations Report 01-4098, $70 \mathrm{p}$.

Shelton, L.R., 1994, Field guide for collecting and processing stream-water samples for the National Water-Quality Assessment Program: U.S. Geological Survey Open-File Report 94-455, $42 \mathrm{p}$.

U.S. Environmental Protection Agency, 1997, Guidelines for preparation of the comprehensive state water quality assessments 305(b) reports and electronic updates: Washington, D.C., Office of Water, EPA 841-B-97-002A and EPA 841-B-97-002B, PL 95-217.

U.S. Environmental Protection Agency, 2002, Drinking-water advisory - Consumer acceptability advice and health effects analysis on sodium: Washington, D.C., Office of Water, EPA 822-R-02-032, 34 p.
U.S. Environmental Protection Agency, 2004, Proposed radon in drinking water rule: Washington, D.C., Office of Water, accessed January 2009, at http://www.epa.gov/safewater/ radon/proposal html.

U.S. Environmental Protection Agency, 2009, National primary drinking water standards and national secondary drinking water standards: Washington, D.C., Office of Water, EPA 816-F-09-0004, 6 p., at http://www.epa.gov/ safewater/consumer/pdf/mcl.pdf.

U.S. Geological Survey, variously dated, National field manual for the collection of water-quality data: U.S. Geological Survey Techniques of Water-Resources Investigations, book 9, chap. A1-A9, at http://pubs.water.usgs.gov/twri9A.

Wilde, F.D., Radtke, D.B., Gibs, Jacob, and Iwatsubo, R.T., eds., 2004, Processing of water samples: U.S. Geological Survey Techniques of Water-Resources Investigations, book 9, chap. A5, variously paged.

Zaugg, S.D., Sandstrom, M.W., Smith, S.G., and Fehlberg, K.M., 1995, Methods of analysis by the U.S. Geological Survey National Water Quality Laboratory-Determination of pesticides in water by $\mathrm{C}-18$ solid-phase extraction and capillary-column gas chromatography with selective-ion monitoring: U.S. Geological Survey Open-File Report 95-181, 49 p. 
Appendix

Tables 1-1 through 1-13 
Table 1-1. Information on wells sampled in the Chemung River Basin, New York, 2008.

[Well locations are shown in figure 1. P, Production; R, Residential; --, information not available]

\begin{tabular}{cccccc}
\hline $\begin{array}{c}\text { Well } \\
\text { number }\end{array}$ & $\begin{array}{c}\text { U.S. Geological } \\
\text { Survey } \\
\text { site identifier }\end{array}$ & $\begin{array}{c}\text { Date } \\
\text { sampled }\end{array}$ & $\begin{array}{c}\text { Well } \\
\text { type }\end{array}$ & $\begin{array}{c}\text { Well depth, } \\
\text { feet below } \\
\text { land surface }\end{array}$ & $\begin{array}{c}\text { Casing depth, } \\
\text { feet below } \\
\text { land surface }\end{array}$ \\
\hline \multicolumn{7}{c}{ Sand and gravel wells } \\
\hline CM 628 & 421058076483401 & $11 / 4 / 2008$ & $\mathrm{P}$ & 72 & 62 \\
SB 383 & 421630077362001 & $11 / 18 / 2008$ & $\mathrm{P}$ & 65 & - - \\
SB 384 & 422130077400001 & $11 / 12 / 2008$ & $\mathrm{P}$ & 67 & 57 \\
SB 1103 & 420630077145001 & $12 / 16 / 2008$ & $\mathrm{P}$ & 76 & 41 \\
SB 1580 & 423118077282001 & $11 / 12 / 2008$ & $\mathrm{P}$ & 100 & 90 \\
\hline & & \multicolumn{2}{c}{ Bedrock wells } & & 30 \\
\hline AG 1047 & 421938077495701 & $10 / 15 / 2008$ & $\mathrm{R}$ & 105 & 41 \\
AG 1176 & 421441077442601 & $11 / 4 / 2008$ & $\mathrm{R}$ & 102 & 55 \\
SB 1272 & 420634077395101 & $10 / 28 / 2008$ & $\mathrm{R}$ & 150 & 18 \\
SB 1470 & 421848077094701 & $11 / 18 / 2008$ & $\mathrm{R}$ & 278 & 40 \\
\hline SB 2326 & 420507077242201 & $12 / 16 / 2008$ & $\mathrm{R}$ & 190 & \\
\hline
\end{tabular}

${ }^{1}$ Prefix denotes county: SB, Steuben; CM, Chemung; AG, Allegany. Number is local well-identification number assigned by U.S. Geological Survey. 
Table 1-2. Compounds for which ground-water samples were analyzed but not detected.

\begin{tabular}{|c|c|c|}
\hline $\begin{array}{c}\text { USGS } \\
\text { parameter } \\
\text { code }\end{array}$ & Constituent & $\begin{array}{c}\text { Laboratory } \\
\text { reporting } \\
\text { level, } \\
\text { micrograms } \\
\text { per liter } \\
(\mu \mathrm{g} / \mathrm{L}) \\
\end{array}$ \\
\hline \multicolumn{3}{|c|}{ Trace elements in unfiltered water } \\
\hline 01097 & Antimony & 0.4 \\
\hline 01012 & Beryllium & 0.02 \\
\hline 01027 & Cadmium & 0.06 \\
\hline 71900 & Mercury & 0.010 \\
\hline 01077 & Silver & 0.06 \\
\hline 01059 & Thallium & 0.12 \\
\hline \multicolumn{3}{|c|}{ Pesticides in filtered water } \\
\hline 04038 & 2-Chloro-6-ethylamino-4-amino-s-triazine (CEAT) & 0.06 \\
\hline 62850 & 2-[(2-Ethyl-6-methylphenyl)amino]-2-oxo ESA & 0.02 \\
\hline 39732 & 2,4-D & 0.06 \\
\hline 50470 & 2,4-D methyl ester & 0.200 \\
\hline 66496 & 2,4-D plus 2,4-D methyl ester & 0.02 \\
\hline 38746 & 2,4-DB & 0.02 \\
\hline 82660 & 2,6-Diethylaniline & 0.006 \\
\hline 49308 & 3-Hydroxy carbofuran & 0.040 \\
\hline 49260 & Acetochlor & $0.010-02$ \\
\hline 61029 & Acetochlor ethanesulfonic acid & 0.02 \\
\hline 61030 & Acetochlor oxanilic acid & 0.02 \\
\hline 63782 & Acetochlor second amide & 0.02 \\
\hline 62847 & Acetochlor sulfynilacetic acid & 0.02 \\
\hline 49315 & Acifluorfen & 0.040 \\
\hline 46342 & Alachlor & $0.008-0.02$ \\
\hline 62849 & Alachlor ESA 2nd amide & 0.02 \\
\hline 61031 & Alachlor oxanilic acid & 0.02 \\
\hline 63781 & Alachlor second amide & 0.02 \\
\hline 62848 & Alachlor sulfynilacetic acid & 0.02 \\
\hline 49313 & Aldicarb sulfone & 0.08 \\
\hline 49314 & Aldicarb sulfoxide & 0.060 \\
\hline 49312 & Aldicarb & 0.12 \\
\hline 34253 & alpha-HCH & 0.008 \\
\hline 82686 & Azinphos-methyl & 0.120 \\
\hline 50299 & Bendiocarb & 0.04 \\
\hline 82673 & Benfluralin & 0.014 \\
\hline 50300 & Benomyl & 0.060 \\
\hline 61693 & Bensulfuron methyl & 0.06 \\
\hline 38711 & Bentazon & 0.06 \\
\hline 04029 & Bromacil & 0.06 \\
\hline 49311 & Bromoxynil & 0.12 \\
\hline
\end{tabular}


Table 1-2. Compounds for which ground-water samples were analyzed but not detected.

\begin{tabular}{|c|c|c|}
\hline $\begin{array}{c}\text { USGS } \\
\text { parameter } \\
\text { code }\end{array}$ & Constituent & $\begin{array}{c}\text { Laboratory } \\
\text { reporting } \\
\text { level, } \\
\text { micrograms } \\
\text { per liter } \\
\text { ( } \mathrm{gg} / \mathrm{L}) \\
\end{array}$ \\
\hline \multicolumn{3}{|c|}{ Pesticides in filtered water-Continued } \\
\hline 04028 & Butylate & 0.002 \\
\hline 50305 & Caffeine & 0.080 \\
\hline 49310 & Carbaryl & 0.04 \\
\hline 49309 & Carbofuran & 0.040 \\
\hline 61188 & Chloramben methyl ester & 0.10 \\
\hline 50306 & Chlorimuron & 0.080 \\
\hline 38933 & Chlorpyrifos & 0.010 \\
\hline 82687 & cis-Permethrin & 0.014 \\
\hline 49305 & Clopyralid & 0.06 \\
\hline 04041 & Cyanazine & 0.040 \\
\hline 04031 & Cycloate & 0.04 \\
\hline 49304 & Dacthal monoacid & 0.04 \\
\hline 82682 & DCPA & 0.006 \\
\hline 63778 & Dechloroacetochlor & 0.02 \\
\hline 63777 & Dechloroalachlor & 0.02 \\
\hline 63779 & Dechlorodimethenamid & 0.02 \\
\hline 63780 & Dechlorometolachlor & 0.02 \\
\hline 62170 & Desulfinyl fipronil & 0.012 \\
\hline 39572 & Diazinon & 0.005 \\
\hline 38442 & Dicamba & 0.04 \\
\hline 49302 & Dichlorprop & 0.04 \\
\hline 39381 & Dieldrin & 0.009 \\
\hline 61951 & Dimethenamid ethanesulfonic acid & 0.02 \\
\hline 62482 & Dimethenamid oxanilic acid & 0.02 \\
\hline 61588 & Dimethenamid & 0.02 \\
\hline 49301 & Dinoseb & 0.04 \\
\hline 04033 & Diphenamid & 0.04 \\
\hline 82677 & Disulfoton & 0.04 \\
\hline 49300 & Diuron & 0.04 \\
\hline 82668 & EPTC & 0.002 \\
\hline 82663 & Ethalfluralin & 0.009 \\
\hline 82672 & Ethoprop & 0.016 \\
\hline 62169 & Desulfinylfipronil amide & 0.029 \\
\hline 49297 & Fenuron & 0.06 \\
\hline 62167 & Fipronil sulfide & 0.013 \\
\hline 62168 & Fipronil sulfone & 0.024 \\
\hline 62166 & Fipronil & 0.040 \\
\hline 61952 & Flufenacet ethanesulfonic acid & 0.02 \\
\hline
\end{tabular}


Table 1-2. Compounds for which ground-water samples were analyzed but not detected.

\begin{tabular}{|c|c|c|}
\hline $\begin{array}{c}\text { USGS } \\
\text { parameter } \\
\text { code }\end{array}$ & Constituent & $\begin{array}{l}\text { Laboratory } \\
\text { reporting } \\
\text { level, } \\
\text { micrograms } \\
\text { per liter } \\
\text { ( } \mu \mathrm{g} / \mathrm{L})\end{array}$ \\
\hline \multicolumn{3}{|c|}{ Pesticides in filtered water-Continued } \\
\hline 62483 & Flufenacet oxanilic acid & 0.02 \\
\hline 62481 & Flufenacet & 0.02 \\
\hline 61694 & Flumetsulam & 0.06 \\
\hline 38811 & Fluometuron & 0.04 \\
\hline 04095 & Fonofos & 0.010 \\
\hline 63784 & Hydroxyacetochlor & 0.02 \\
\hline 63783 & Hydroxyalachlor & 0.02 \\
\hline 63785 & Hydroxymetolachlor & 0.02 \\
\hline 64045 & Hydroxydimethenamid & 0.02 \\
\hline 50356 & Imazaquin & 0.06 \\
\hline 50407 & Imazethapyr & 0.06 \\
\hline 61695 & Imidacloprid & 0.060 \\
\hline 39341 & Lindane & 0.014 \\
\hline 82666 & Linuron & 0.060 \\
\hline 39532 & Malathion & 0.020 \\
\hline 38482 & MCPA & 0.04 \\
\hline 38487 & МСРВ & 0.20 \\
\hline 50359 & Metalaxyl & 0.04 \\
\hline 38501 & Methiocarb & 0.040 \\
\hline 49296 & Methomyl & $0.060-0.120$ \\
\hline 82667 & Methyl parathion & 0.008 \\
\hline 39415 & Metolachlor & $0.014-0.02$ \\
\hline 61044 & Metolachlor OA & 0.02 \\
\hline 82630 & Metribuzin & 0.016 \\
\hline 61697 & Metsulfuron & 0.14 \\
\hline 82671 & Molinate & 0.002 \\
\hline 61692 & $\mathrm{~N}$-(4-Chlorophenyl)-N'-methylurea & 0.06 \\
\hline 82684 & Napropamide & 0.018 \\
\hline 49294 & Neburon & 0.02 \\
\hline 50364 & Nicosulfuron & 0.10 \\
\hline 49293 & Norflurazon & 0.04 \\
\hline 49292 & Oryzalin & 0.04 \\
\hline 38866 & Oxamyl & 0.12 \\
\hline 34653 & $\mathrm{p}, \mathrm{p}$ '-DDE & 0.003 \\
\hline 39542 & Parathion & 0.020 \\
\hline 82669 & Pebulate & 0.016 \\
\hline 82683 & Pendimethalin & 0.012 \\
\hline 82664 & Phorate & 0.020 \\
\hline
\end{tabular}


Table 1-2. Compounds for which ground-water samples were analyzed but not detected.

\begin{tabular}{|c|c|c|}
\hline $\begin{array}{l}\text { USGS } \\
\text { parameter } \\
\text { code }\end{array}$ & Constituent & $\begin{array}{c}\text { Laboratory } \\
\text { reporting } \\
\text { level, } \\
\text { micrograms } \\
\text { per liter } \\
\text { ( } \mathrm{gg} / \mathrm{L}) \\
\end{array}$ \\
\hline & Pesticides in filtered water-Continued & \\
\hline 49291 & Picloram & 0.12 \\
\hline 04037 & Prometon & 0.1 \\
\hline 82676 & Propyzamide & 0.004 \\
\hline 04024 & Propachlor & $0.012-0.02$ \\
\hline 62766 & Propachlor ethanesulfonic acid & 0.05 \\
\hline 62767 & Propachlor oxanilic acid & 0.02 \\
\hline 82679 & Propanil & 0.014 \\
\hline 82685 & Propargite & 0.02 \\
\hline 49236 & Propham & 0.040 \\
\hline 50471 & Propiconazole & 0.04 \\
\hline 38538 & Propoxur & 0.060 \\
\hline 38548 & Siduron & 0.04 \\
\hline 04035 & Simazine & 0.010 \\
\hline 50337 & Sulfometuron & 0.060 \\
\hline 82670 & Tebuthiron & 0.02 \\
\hline 82665 & Terbacil & 0.040 \\
\hline 82675 & Terbufos & 0.02 \\
\hline 82681 & Thiobencarb & 0.016 \\
\hline 82678 & Triallate & 0.006 \\
\hline 49235 & Triclopyr & 0.08 \\
\hline 82661 & Trifluralin & 0.012 \\
\hline \multicolumn{3}{|c|}{ Volatile organic compounds, in unfiltered water } \\
\hline 77652 & 1,1,1-Trichloro-1,2,2-trifluoroethane & 0.1 \\
\hline 34496 & 1,1-Dichloroethane & 0.1 \\
\hline 34501 & 1,1-Dichloroethene & 0.1 \\
\hline 34536 & 1,2-Dichlorobenzene & 0.1 \\
\hline 32103 & 1,2-Dichloroethane & 0.2 \\
\hline 34541 & 1,2-Dichloropropane & 0.1 \\
\hline 34566 & 1,3-Dichlorobenzene & 0.1 \\
\hline 34571 & 1,4-Dichlorobenzene & 0.1 \\
\hline 34030 & Benzene & 0.1 \\
\hline 32101 & Bromodichloromethane & 0.1 \\
\hline 34301 & Chlorobenzene & 0.1 \\
\hline 77093 & cis-1,2 Dichloroethene & 0.1 \\
\hline 32105 & Dibromochloromethane & 0.2 \\
\hline 34668 & Dichlorodifluoromethane & 0.2 \\
\hline 34423 & Dichloromethane & 0.2 \\
\hline 81576 & Diethyl ether & 0.2 \\
\hline
\end{tabular}


Table 1-2. Compounds for which ground-water samples were analyzed but not detected.

\begin{tabular}{clc}
\hline $\begin{array}{c}\text { USGS } \\
\text { parameter } \\
\text { code }\end{array}$ & \multicolumn{1}{c}{ Constituent } & $\begin{array}{c}\text { Laboratory } \\
\text { reporting } \\
\text { level, } \\
\text { micrograms } \\
\text { per liter } \\
\text { ( } \mathbf{g} / \mathbf{L})\end{array}$ \\
\hline & Volatile organic compounds, in unfiltered water-Continued \\
\hline 81577 & Diisopropyl ether & 0.2 \\
34371 & Ethylbenzene & 0.1 \\
50005 & Methyl tert-pentyl ether & 0.2 \\
85795 & m+ p Xylene & 0.2 \\
77135 & o-Xylene & 0.1 \\
77128 & Styrene & 0.1 \\
50004 & tert-Butyl ethyl ether & 0.1 \\
32102 & Tetrachloromethane & 0.2 \\
34546 & trans-1,2-Dichloroethene & 0.1 \\
32104 & Tribromomethane & 0.2 \\
34488 & Trichlorofluoromethane & 0.2 \\
39175 & Vinyl Choride & 0.2 \\
32730 & Phenolic Compounds & 4 \\
\hline
\end{tabular}

Table 1-3. Physical properties of groundwater samples from the Chemung River Basin, New York, 2008.

[Well locations are shown in figure 1. mg/L, milligrams per liter; <, less than; $\mu \mathrm{S} / \mathrm{cm}$, microsiemens per centimeter at 25 degrees Celsius; (00080), U.S. Geological Survey National Water Information System (NWIS) parameter code; M, detected but not quantified]

\begin{tabular}{|c|c|c|c|c|c|c|}
\hline $\begin{array}{c}\text { Well } \\
\text { number }^{1}\end{array}$ & $\begin{array}{l}\text { Water color } \\
\text { filtered, } \\
\text { platinum } \\
\text { cobalt units } \\
(\mathbf{0 0 0 8 0 )}\end{array}$ & $\begin{array}{c}\text { Dissolved- } \\
\text { oxygen } \\
\text { concentration, } \\
\text { field, } \mathrm{mg} / \mathrm{L} \\
(00300)\end{array}$ & $\begin{array}{c}\text { pH, field, } \\
\text { standard } \\
\text { units } \\
(00400)\end{array}$ & $\begin{array}{c}\text { Specific } \\
\text { conductance, } \\
\text { field, } \mu \mathrm{SS} / \mathrm{cm} \\
(00095)\end{array}$ & $\begin{array}{c}\text { Water } \\
\text { temperature, } \\
\text { degrees Celsius } \\
(00010)\end{array}$ & $\begin{array}{c}\text { Hydrogen } \\
\text { sulfide } \\
\text { (71875) }\end{array}$ \\
\hline \multicolumn{7}{|c|}{ Sand and gravel wells } \\
\hline CM 628 & 5 & 5.4 & 7.7 & 435 & 14.0 & Absent \\
\hline SB 383 & $<1$ & .6 & 7.2 & 822 & 11.0 & Absent \\
\hline SB 384 & 5 & 2.4 & 7.4 & 778 & 11.0 & Absent \\
\hline SB 1103 & 5 & $<.3$ & 7.6 & 461 & 10.3 & Absent \\
\hline SB 1580 & 8 & .5 & 7.7 & 498 & 10.2 & Absent \\
\hline \multicolumn{7}{|c|}{ Bedrock wells } \\
\hline AG 1047 & 5 & $<.1$ & 7.5 & 1,080 & 15.1 & M \\
\hline AG 1176 & 5 & 1.1 & 7.5 & 277 & 11.6 & Absent \\
\hline SB 1272 & 8 & 2.8 & 7.4 & 538 & 8.6 & Absent \\
\hline SB 1470 & 2 & 5.2 & 7.0 & 316 & 11.7 & Absent \\
\hline SB 2326 & 5 & 4.2 & 7.5 & 737 & 8.8 & Absent \\
\hline
\end{tabular}

${ }^{1}$ Prefix denotes county: SB, Steuben; CM, Chemung; AG, Allegany. Number is local well-identification number assigned by U.S. Geological Survey. 
Table 1-4. Concentrations of inorganic constituents in groundwater samples from the Chemung River Basin, New York, 2008.

[Well locations are shown in figure 1. mg/L, milligrams per liter; (00900), U.S. Geological Survey National Water Information System (NWIS) parameter code; $\mathrm{CaCO}_{3}$, calcium carbonate; E, estimated value — constituent was detected inthe sample but with low or inconsistent recovery. Bold values exceed one or more drinking-water standards]

\begin{tabular}{|c|c|c|c|c|c|c|c|}
\hline $\begin{array}{c}\text { Well } \\
\text { number }^{1}\end{array}$ & $\begin{array}{c}\text { Hardness, } \\
\text { filtered, } \\
\mathrm{mg} / \mathrm{L} \text { as CaCO } \\
(00900)\end{array}$ & $\begin{array}{c}\text { Calcium, } \\
\text { filtered, } \\
\text { mg/L } \\
\text { (00915) }\end{array}$ & $\begin{array}{l}\text { Magnesium, } \\
\text { filtered, } \\
\text { mg/L } \\
(00925)\end{array}$ & $\begin{array}{l}\text { Potassium, } \\
\text { filtered, } \\
\text { mg/L } \\
(00935)\end{array}$ & $\begin{array}{c}\text { Sodium, } \\
\text { filtered, } \\
\text { mg/L } \\
(00930)\end{array}$ & $\begin{array}{c}\text { Acid- } \\
\text { neutralizing } \\
\text { capacity, } \\
\text { unfiltered, } \\
\text { mg/L as } \mathrm{CaCO}_{3} \\
(90410)\end{array}$ & $\begin{array}{c}\text { Alkalinity, } \\
\text { filtered, } \\
\text { mg/L as } \mathrm{CaCO}_{3} \\
\text { (29801) }\end{array}$ \\
\hline \multicolumn{8}{|c|}{ Sand and gravel wells } \\
\hline SB 383 & 320 & 99.9 & 16.8 & 4.20 & 46.2 & 273 & 273 \\
\hline SB 384 & 270 & 78.2 & 18.3 & 2.09 & 56.2 & 228 & 228 \\
\hline SB 1103 & 180 & 58.1 & 8.97 & 0.77 & 26.4 & 150 & 149 \\
\hline SB 1580 & 230 & 65.3 & 16.9 & 1.31 & 12.0 & 153 & 153 \\
\hline \multicolumn{8}{|c|}{ Bedrock wells } \\
\hline SB 1470 & 140 & 40.3 & 9.18 & 1.46 & 6.35 & 106 & 106 \\
\hline SB 2326 & 310 & 108 & 10.8 & 2.03 & 24.6 & 178 & 178 \\
\hline
\end{tabular}

\begin{tabular}{|c|c|c|c|c|c|c|}
\hline $\begin{array}{c}\text { Well } \\
\text { number }^{1}\end{array}$ & $\begin{array}{l}\text { Bicarbonate, } \\
\text { filtered, } \\
\text { mg/L as CaCO } \\
\text { (29805) }\end{array}$ & $\begin{array}{c}\text { Chloride, } \\
\text { filtered, } \\
\mathrm{mg} / \mathrm{L} \\
(00940)\end{array}$ & $\begin{array}{c}\text { Fluoride, } \\
\text { filtered, } \\
\mathrm{mg} / \mathrm{L} \\
(00950)\end{array}$ & $\begin{array}{c}\text { Silica, } \\
\text { filtered, } \\
\text { mg/L } \\
\text { (00955) }\end{array}$ & $\begin{array}{c}\text { Sulfate, } \\
\text { filtered, } \\
\text { mg/L } \\
\text { (00945) }\end{array}$ & $\begin{array}{c}\text { Residue on } \\
\text { evaporation, } \\
\text { at } 180^{\circ} \text { Celsius, } \\
\text { filtered, } \\
\mathrm{mg} / \mathrm{L} \\
(70300)\end{array}$ \\
\hline \multicolumn{7}{|c|}{ Sand and gravel wells } \\
\hline SB 383 & 333 & 83.8 & Е.07 & 8.29 & 23.3 & 460 \\
\hline SB 384 & 278 & 87.8 & E. 06 & 8.63 & 33.1 & 440 \\
\hline SB 1103 & 182 & 49.2 & E.08 & 8.91 & 10.6 & 264 \\
\hline SB 1580 & 187 & 31.5 & E.06 & 8.55 & 49.5 & 282 \\
\hline \multicolumn{7}{|c|}{ Bedrock wells } \\
\hline SB 1470 & 129 & 9.27 & .14 & 11.6 & 28.3 & 184 \\
\hline SB 2326 & 217 & 99.1 & .12 & 9.27 & 26.5 & 440 \\
\hline
\end{tabular}

\footnotetext{
${ }^{1}$ Prefix denotes county: SB, Steuben; CM, Chemung; AG, Allegany. Number is local well-identification number assigned by U.S. Geological Survey.

${ }^{2}$ Fixed-endpoint titration at $\mathrm{pH} 4.5$.

${ }^{3}$ Calculated from alkalinity.
} 
Table 1-5. Concentrations of nutrients and total organic carbon in groundwater samples from the Chemung River Basin, New York, 2008.

[Well locations are shown in figure 1. mg/L, milligrams per liter; N, nitrogen; P, phosphorus; <, less than; (00623), U.S. Geological Survey National Water Information System (NWIS) parameter code; E, estimated value - constituent was detected in the sample but with low or inconsistent recovery]

\begin{tabular}{|c|c|c|c|c|c|c|}
\hline $\begin{array}{c}\text { Well } \\
\text { number }\end{array}$ & $\begin{array}{c}\text { Ammonia plus } \\
\text { organic nitrogen, } \\
\text { filtered, } \\
\text { mg/L as N } \\
\text { (00623) }\end{array}$ & $\begin{array}{c}\text { Ammonia, } \\
\text { filtered, } \\
\text { mg/L as N } \\
\text { (00608) }\end{array}$ & $\begin{array}{l}\text { Nitrate plus } \\
\text { nitrite, } \\
\text { filtered, } \\
\text { mg/L as N } \\
\text { (00631) }\end{array}$ & $\begin{array}{c}\text { Nitrite, } \\
\text { filtered, } \\
\text { mg/L as N } \\
\text { (00613) }\end{array}$ & $\begin{array}{l}\text { Orthophosphate, } \\
\text { filtered, } \\
\text { mg/L as P } \\
\text { (00671) }\end{array}$ & $\begin{array}{c}\text { Total organic } \\
\text { carbon, } \\
\text { unfiltered, } \\
\text { mg/L } \\
(\mathbf{0 0 6 8 0 )}\end{array}$ \\
\hline \multicolumn{7}{|c|}{ Sand and gravel wells } \\
\hline CM 628 & E 0.06 & $<0.020$ & 0.25 & $<0.002$ & E 0.006 & 1.1 \\
\hline SB 383 & $<.10$ & $<.020$ & 2.29 & $<.002$ & $<.008$ & .9 \\
\hline SB 384 & $<.10$ & $<.020$ & 1.71 & .002 & E.005 & E.4 \\
\hline SB 1103 & .18 & .123 & $<.04$ & $<.002$ & .103 & 1.1 \\
\hline SB 1580 & $<.10$ & $<.020$ & 1.21 & .044 & .008 & 1.0 \\
\hline \multicolumn{7}{|c|}{ Bedrock wells } \\
\hline AG 1047 & .65 & .596 & $<.04$ & $<.002$ & E.006 & 2.1 \\
\hline AG 1176 & $<.10$ & $<.020$ & $<.04$ & $<.002$ & E.006 & $<1.0$ \\
\hline SB 1272 & .16 & $<.020$ & .05 & $<.002$ & E.007 & 1.5 \\
\hline SB 1470 & .13 & $<.020$ & 3.00 & $<.002$ & E.006 & 2.2 \\
\hline SB 2326 & $<.10$ & $<.020$ & 3.67 & $<.002$ & E .005 & E. 5 \\
\hline
\end{tabular}

${ }^{1}$ Prefix denotes county: SB, Steuben; CM, Chemung; AG, Allegany. Number is local well-identification number assigned by U.S. Geological Survey. 
Table 1-6. Concentrations of trace elements and radon-222 in groundwater samples from the Chemung River Basin, New York, 2008.

[Well locations are shown in figure 1. $\mu \mathrm{g} / \mathrm{L}$, micrograms per liter; (01105), U.S. Geological Survey National Water Information System (NWIS) parameter code; <, less than; E, estimated value — constituent was detected in the sample but with low or inconsistent recovery; $\mathrm{pCi} / \mathrm{L}$, picocuries per liter. Bold values exceed one or more drinking-water standards]

\begin{tabular}{|c|c|c|c|c|c|c|c|}
\hline $\begin{array}{c}\text { Well } \\
\text { number }{ }^{1}\end{array}$ & $\begin{array}{c}\text { Aluminum, } \\
\text { unfiltered, } \\
\mu \mathrm{g} / \mathrm{L} \\
(01105)\end{array}$ & $\begin{array}{c}\text { Arsenic, } \\
\text { unfiltered, } \\
\mu \mathrm{g} / \mathrm{L} \\
(01002)\end{array}$ & $\begin{array}{c}\text { Barium, } \\
\text { unfiltered, } \\
\mu \mathrm{g} / \mathrm{L} \\
(01007)\end{array}$ & $\begin{array}{c}\text { Boron, } \\
\text { filtered, } \\
\mu \mathrm{g} / \mathrm{L} \\
(01020)\end{array}$ & $\begin{array}{c}\text { Chromium, } \\
\text { unfiltered, } \\
\mu \mathrm{g} / \mathrm{L} \\
(01034)\end{array}$ & $\begin{array}{c}\text { Cobalt, } \\
\text { unfiltered, } \\
\mu \mathrm{g} / \mathrm{L} \\
(01037)\end{array}$ & $\begin{array}{c}\text { Copper, } \\
\text { unfiltered, } \\
\mu \mathrm{g} / \mathrm{L} \\
(01042)\end{array}$ \\
\hline \multicolumn{8}{|c|}{ Sand and gravel wells } \\
\hline CM 628 & $<6$ & 0.22 & 152 & 16 & $<0.40$ & $<0.10$ & $<4.0$ \\
\hline SB 383 & $<6$ & E.18 & 267 & 38 & $<.40$ & E.07 & 4.2 \\
\hline SB 1103 & $<6$ & 7.5 & 937 & 17 & $<.40$ & $<.10$ & $<4.0$ \\
\hline SB 1580 & $<6$ & .99 & 294 & 9.4 & $<.40$ & $<.10$ & $<4.0$ \\
\hline \multicolumn{8}{|c|}{ Bedrock wells } \\
\hline AG 1047 & 27 & $<.20$ & 411 & 372 & $<.40$ & $<.10$ & $<4.0$ \\
\hline SB 2326 & 69 & .30 & 220 & 18 & E. 21 & .16 & E 2.4 \\
\hline
\end{tabular}

'Prefix denotes county: SB, Steuben; CM, Chemung; AG, Allegany. Number is local well-identification number assigned by U.S. Geological Survey.

Table 1-6. Concentrations of trace elements and radon-222 in groundwater samples from the Chemung River Basin, New York, 2008.-Continued

[Well locations are shown in figure 1. $\mu \mathrm{g} / \mathrm{L}$, micrograms per liter; (01046), U.S. Geological Survey National Water Information System (NWIS) parameter code; <, less than; E, estimated value - constituent was detected in the sample but with low or inconsistent recovery; $\mathrm{M}$, measured but not quantified. Bold values exceed one or more drinking-water standards]

\begin{tabular}{|c|c|c|c|c|c|c|}
\hline $\begin{array}{c}\text { Well } \\
\text { number }\end{array}$ & $\begin{array}{c}\text { Iron, } \\
\text { filtered, } \\
\mu \mathrm{g} / \mathrm{L} \\
(01046)\end{array}$ & $\begin{array}{c}\text { Iron, } \\
\text { unfiltered, } \\
\mu \mathrm{g} / \mathrm{L} \\
(01045)\end{array}$ & $\begin{array}{c}\text { Lead, } \\
\text { unfiltered, } \\
\mu \mathrm{g} / \mathrm{L} \\
(01051)\end{array}$ & $\begin{array}{c}\text { Lithium, } \\
\text { unfiltered, } \\
\mu \mathrm{g} / \mathrm{L} \\
(\mathbf{0 1 1 3 2})\end{array}$ & $\begin{array}{c}\text { Manganese, } \\
\text { filtered, } \\
\mu \mathrm{g} / \mathrm{L} \\
(01056)\end{array}$ & $\begin{array}{c}\text { Manganese, } \\
\text { unfiltered, } \\
\mu \mathrm{g} / \mathrm{L} \\
(01055)\end{array}$ \\
\hline \multicolumn{7}{|c|}{ Sand and gravel wells } \\
\hline CM 628 & $<4$ & $<14$ & 0.13 & 1.5 & $<0.2$ & 1.1 \\
\hline SB 383 & $<4$ & $<14$ & .53 & 3.6 & 198 & 230 \\
\hline SB 384 & 18 & 18 & .42 & 7.6 & 18.7 & 21.4 \\
\hline SB 1103 & 503 & 507 & $<.10$ & 15.0 & 141 & 143 \\
\hline SB 1580 & 15 & 16 & 1.15 & 6.3 & 57.5 & 58.3 \\
\hline \multicolumn{7}{|c|}{ Bedrock wells } \\
\hline AG 1047 & 76 & 126 & .14 & 104 & 33.5 & 36.9 \\
\hline AG 1176 & E 4 & E 9 & .22 & 12.1 & 29.5 & 75.1 \\
\hline SB 1272 & $<4$ & $<14$ & .22 & 29.0 & 2.1 & 5.4 \\
\hline SB 1470 & E 3 & 40 & .50 & 10.4 & .3 & 10.1 \\
\hline SB 2326 & 10 & 105 & 1.36 & 12.3 & 3.2 & 5.1 \\
\hline
\end{tabular}


Table 1-6. Concentrations of trace elements and radon-222 in groundwater samples from the Chemung River Basin, New York, 2008. -Continued

[Well locations are shown in figure 1. $\mu \mathrm{g} / \mathrm{L}$, micrograms per liter; (01046), U.S. Geological Survey National Water Information System (NWIS) parameter code; <, less than; E, estimated value - constituent was detected in the sample but with low or inconsistent recovery; M, measured but not quantified. Bold values exceed one or more drinking-water standards]

\begin{tabular}{|c|c|c|c|c|c|c|c|}
\hline $\begin{array}{c}\text { Well } \\
\text { number }\end{array}$ & $\begin{array}{c}\text { Molybdenum, } \\
\text { unfiltered, } \\
\mu \mathrm{g} / \mathrm{L} \\
(\mathbf{0 1 0 6 2})\end{array}$ & $\begin{array}{c}\text { Nickel, } \\
\text { unfiltered, } \\
\mu \mathrm{g} / \mathrm{L} \\
(01067)\end{array}$ & $\begin{array}{c}\text { Selenium, } \\
\text { unfiltered, } \\
\mu \mathrm{g} / \mathrm{L} \\
(01147)\end{array}$ & $\begin{array}{c}\text { Strontium, } \\
\text { unfiltered, } \\
\mu \mathrm{g} / \mathrm{L} \\
(\mathbf{0 1 0 8 2})\end{array}$ & $\begin{array}{c}\text { Radon-222, } \\
\text { unfiltered, } \\
\text { pCi/L } \\
(\mathbf{8 2 3 0 3 )}\end{array}$ & $\begin{array}{c}\text { Uranium, } \\
\text { (natural), } \\
\text { unfiltered, } \\
\mu \mathrm{g} / \mathrm{L} \\
(28011)\end{array}$ & $\begin{array}{c}\text { Zinc, } \\
\text { unfiltered, } \\
\mu \mathrm{g} / \mathrm{L} \\
(01092)\end{array}$ \\
\hline \multicolumn{8}{|c|}{ Sand and gravel wells } \\
\hline CM 628 & 0.1 & E 0.17 & $<0.12$ & 110 & 450 & 0.177 & 4.6 \\
\hline SB 383 & .2 & .50 & .16 & 194 & 600 & .237 & 12.4 \\
\hline SB 384 & .3 & .25 & Е .07 & 116 & 420 & .620 & E 2.0 \\
\hline SB 1103 & .5 & .33 & $<.12$ & 199 & 520 & .025 & E 1.6 \\
\hline SB 1580 & 1.0 & .29 & .21 & 118 & 290 & .427 & 2.2 \\
\hline \multicolumn{8}{|c|}{ Bedrock wells } \\
\hline AG 1047 & $<.1$ & .26 & .15 & 275 & 153 & $<.020$ & 5.1 \\
\hline AG 1176 & .8 & .25 & $<.12$ & 50.1 & 1,740 & .456 & 3.7 \\
\hline SB 1272 & .3 & E.11 & $<.12$ & 638 & 1,430 & 1.64 & 24.6 \\
\hline SB 1470 & .1 & .41 & $<.12$ & 227 & 1,460 & .104 & 6.9 \\
\hline SB 2326 & .2 & .48 & $<.12$ & 226 & 1,120 & .809 & 2.4 \\
\hline
\end{tabular}

Table 1-7. Concentrations of pesticides detected in groundwater samples from the Chemung River Basin, New York, 2008.

[Well locations are shown in figure 1. $\mu \mathrm{g} / \mathrm{L}$, micrograms per liter; <, less than; (04040), U.S. Geological Survey National Water Information System (NWIS) parameter code; CIAT, 2-Chloro-4-isopropylamino-6-amino-s-triazine; OIET, 2-Hydroxy-4isopropylamino-6-ethylamino-s-triazine; ESA, ethanesulfonic acid; E, estimated value - constituent was detected in the sample but with low or inconsistent recovery]

\begin{tabular}{|c|c|c|c|c|c|}
\hline $\begin{array}{c}\text { Well } \\
\text { number }\end{array}$ & $\begin{array}{c}\text { CIAT, } \\
\text { filtered, } \\
\mu \mathrm{g} / \mathrm{L} \\
(04040)\end{array}$ & $\begin{array}{c}\text { OIET } \\
\text { filtered, } \\
\mu \mathrm{g} / \mathrm{L} \\
(\mathbf{5 0 3 5 5 )}\end{array}$ & $\begin{array}{c}\text { Alachlor ESA, } \\
\text { filtered, } \\
\mu \mathrm{g} / \mathrm{L} \\
(\mathbf{5 0 0 0 9 )}\end{array}$ & $\begin{array}{c}\text { Atrazine, } \\
\text { filtered, } \\
\mu \mathrm{g} / \mathrm{L} \\
(39632)\end{array}$ & $\begin{array}{c}\text { Metolachlor } \\
\text { ESA, } \\
\text { filtered, } \\
\mathbf{p g} / \mathrm{L} \\
(61043)\end{array}$ \\
\hline \multicolumn{6}{|c|}{ Sand and gravel wells } \\
\hline CM 628 & E 0.009 & E 0.007 & $<0.02$ & E 0.002 & $<0.02$ \\
\hline SB 383 & E.002 & $<.060$ & .02 & $<.007$ & .09 \\
\hline SB 384 & Е.003 & $<.060$ & .03 & $<.007$ & .11 \\
\hline SB 1103 & $<.014$ & $<.060$ & $<.02$ & $<.007$ & $<.02$ \\
\hline SB 1580 & $<.014$ & $<.060$ & $<.02$ & $<.007$ & .06 \\
\hline \multicolumn{6}{|c|}{ Bedrock wells } \\
\hline AG 1047 & $<.014$ & $<.060$ & $<.02$ & $<.007$ & $<.02$ \\
\hline AG 1176 & $<.014$ & $<.060$ & $<.02$ & $<.007$ & $<.02$ \\
\hline SB 1272 & $<.014$ & $<.060$ & $<.02$ & $<.007$ & $<.02$ \\
\hline SB 1470 & $<.014$ & $<.060$ & $<.02$ & $<.007$ & $<.02$ \\
\hline SB 2326 & $<.014$ & $<.060$ & $<.02$ & $<.007$ & $<.02$ \\
\hline
\end{tabular}

\footnotetext{
${ }^{1}$ Prefix denotes county: SB, Steuben; CM, Chemung; AG, Allegany. Number is local well-identification number assigned by U.S. Geological Survey.
} 
Table 1-8. Concentrations of volatile organic compounds in groundwater samples from the Chemung River Basin, New York, 2008.

[Well locations are shown in figure 1. $\mu \mathrm{g} / \mathrm{L}$, micrograms per liter; <, less than; (34506), U.S. Geological Survey National Water Information System parameter code. Bold values indicate detections]

\begin{tabular}{|c|c|c|c|c|c|c|}
\hline $\begin{array}{c}\text { Well } \\
\text { number }\end{array}$ & $\begin{array}{c}1,1,1- \\
\text { Trichloro- } \\
\text { ethane, } \\
\text { unfiltered, } \\
\mu \mathrm{g} / \mathrm{L} \\
(34506)\end{array}$ & $\begin{array}{c}\text { Trichloro- } \\
\text { methane, } \\
\text { unfiltered, } \\
\mu \mathrm{g} / \mathrm{L} \\
(32106)\end{array}$ & $\begin{array}{c}\text { Toluene, } \\
\text { unfiltered, } \\
\mu \mathrm{g} / \mathrm{L} \\
(\mathbf{3 4 0 1 0 )}\end{array}$ & $\begin{array}{c}\text { Trichloro- } \\
\text { ethene, } \\
\text { unfiltered, } \\
\mu \mathrm{g} / \mathrm{L} \\
(39180)\end{array}$ & $\begin{array}{c}\text { Tetrachloro- } \\
\text { ethene, } \\
\text { unfiltered, } \\
\mu \mathrm{gg} / \mathrm{L} \\
(34475)\end{array}$ & $\begin{array}{c}\text { Methyl } \\
\text { tert-butyl } \\
\text { ether, } \\
\text { unfiltered, } \\
\mu \mathrm{g} / \mathrm{L} \\
\text { (78032) }\end{array}$ \\
\hline \multicolumn{7}{|c|}{ Sand and gravel wells } \\
\hline CM 628 & $<0.1$ & $<0.1$ & $<0.1$ & $<0.1$ & $<0.1$ & $<0.2$ \\
\hline SB 383 & $<.1$ & $<.1$ & $<.1$ & $<.1$ & 3.3 & 0.4 \\
\hline SB 384 & 0.1 & 5.7 & $<.1$ & 5.5 & $<.1$ & $<.2$ \\
\hline SB 1103 & $<.1$ & $<.1$ & $<.1$ & $<.1$ & $<.1$ & $<.2$ \\
\hline SB 1580 & $<.1$ & $<.1$ & $<.1$ & $<.1$ & $<.1$ & $<.2$ \\
\hline \multicolumn{7}{|c|}{ Bedrock wells } \\
\hline AG 1047 & $<.1$ & $<.1$ & $<.1$ & $<.1$ & $<.1$ & $<.2$ \\
\hline AG 1176 & $<.1$ & $<.1$ & $<.1$ & $<.1$ & $<.1$ & $<.2$ \\
\hline SB 1272 & $<.1$ & $<.1$ & 0.2 & $<.1$ & $<.1$ & $<.2$ \\
\hline SB 1470 & $<.1$ & $<.1$ & $<.1$ & $<.1$ & $<.1$ & $<.2$ \\
\hline SB 2326 & $<.1$ & 0.2 & $<.1$ & $<.1$ & $<.1$ & $<.2$ \\
\hline
\end{tabular}

${ }^{1}$ Prefix denotes county: SB, Steuben; CM, Chemung; AG, Allegany. Number is local well-identification number assigned by U.S. Geological Survey.

Table 1-9. Concentrations of bacteria in unfiltered groundwater samples from the Chemung River Basin, New York, 2008.

[Well locations are shown in figure 1. mL, milliliter; <, less than; > greater than; CFU, colony-forming unit; (61213), U.S. Geological Survey National Water Information System (NWIS) parameter code. Bold values exceed one or more drinking-water standards]

\begin{tabular}{|c|c|c|c|c|}
\hline $\begin{array}{c}\text { Well } \\
\text { number' }\end{array}$ & $\begin{array}{c}\text { Total coliform } \\
\text { colonies per } 100 \mathrm{~mL} \\
\text { (61213) }\end{array}$ & $\begin{array}{c}\text { Fecal coliform } \\
\text { colonies per } 100 \mathrm{~mL} \\
(61215)\end{array}$ & $\begin{array}{c}\text { Escherichia coli, } \\
\text { colonies per } 100 \mathrm{~mL} \\
\text { (31691) }\end{array}$ & $\begin{array}{c}\text { Heterotrophic } \\
\text { plate count, } \\
\text { CFUs per mL } \\
\text { (31692) }\end{array}$ \\
\hline \multicolumn{5}{|c|}{ Sand and gravel wells } \\
\hline CM 628 & 18 & $<1$ & $<1$ & 6 \\
\hline SB 383 & $<1$ & $<1$ & $<1$ & 8 \\
\hline SB 384 & $<1$ & $<1$ & $<1$ & 2 \\
\hline SB 1103 & $<1$ & $<1$ & $<1$ & $<1$ \\
\hline SB 1580 & $<1$ & $<1$ & $<1$ & 5 \\
\hline \multicolumn{5}{|c|}{ Bedrock wells } \\
\hline AG 1047 & $<1$ & $<1$ & $<1$ & 3 \\
\hline AG 1176 & 1 & $<1$ & $<1$ & 6 \\
\hline SB 1272 & $<1$ & $<1$ & $<1$ & 91 \\
\hline SB 1470 & $>\mathbf{2 0 0}$ & $<1$ & $<1$ & 233 \\
\hline SB 2326 & 100 & 1 & $<1$ & 403 \\
\hline
\end{tabular}

${ }^{1}$ Prefix denotes county: SB, Steuben; CM, Chemung; AG, Allegany. Number is local well-identification number assigned by U.S. Geological Survey. 
Table 1-10. Physical properties of, and concentrations of major ions, nutrients, total organic carbon, and bacteria in groundwater samples collected in the Chemung River Basin, New York, 2003 and 2008.

[Well locations are shown in figure 1. NWIS, National Water Information System; wu, unfiltered water; wf, filtered water; mg/L, milligrams per liter, $\mu \mathrm{S} / \mathrm{cm}$, microsiemens per centimeter at 25 degrees Celsius; N, nitrogen; P, phosphorus; CFU, colony-forming unit; mL, milliliter; pos, positive result (organism detected); <, less than; >, greater than; E, estimated value - constituent was detected in the sample but with low or inconsistent recovery]

\begin{tabular}{|c|c|c|c|c|c|}
\hline \multirow{2}{*}{$\begin{array}{l}\text { U.S. Geological Survey } \\
\text { NWIS parameter code }\end{array}$} & \multirow{2}{*}{ Constituent } & \multicolumn{2}{|c|}{ Well SB 1470} & \multicolumn{2}{|c|}{ Well CM 628} \\
\hline & & 2003 & 2008 & 2003 & 2008 \\
\hline \multicolumn{6}{|c|}{ Physical properties } \\
\hline 00080 & Color, wf, platinum-cobalt units & $<1$ & 2 & 2 & 5 \\
\hline 00300 & Dissolved oxygen, wu, mg/L & 5.4 & 5.2 & 6.0 & 5.4 \\
\hline 00400 & $\mathrm{pH}, \mathrm{wu}$ & 8.4 & 7.0 & 8.0 & 7.7 \\
\hline 00095 & Specific conductance, wu, $\mu \mathrm{S} / \mathrm{cm}$ & 374 & 316 & 393 & 435 \\
\hline 00010 & Temperature, wu, degrees Celsius & 11.2 & 11.7 & 14.4 & 14.0 \\
\hline \multicolumn{6}{|c|}{ Inorganic constituents (major ions) } \\
\hline 00915 & Calcium, wf, $\mathrm{mg} / \mathrm{L}$ & 50.3 & 40.3 & 43.0 & 49.5 \\
\hline 00925 & Magnesium, wf, mg/L & 11.4 & 9.18 & 8.41 & 10.0 \\
\hline 00935 & Potassium, wf, mg/L & 1.48 & 1.46 & 1.64 & 1.75 \\
\hline 00930 & Sodium, wf, mg/L & 6.98 & 6.35 & 21.2 & 22.1 \\
\hline 00940 & Chloride, $\mathrm{wf}, \mathrm{mg} / \mathrm{L}$ & 10.1 & 9.27 & 41.7 & 40.5 \\
\hline 00950 & Fluoride, $w f, \mathrm{mg} / \mathrm{L}$ & $<0.2$ & 0.14 & $<0.2$ & Е 0.07 \\
\hline 00955 & Silica, wf, mg/L & 13.3 & 11.6 & 5.54 & 5.34 \\
\hline 00945 & Sulfate, wf, mg/L & 24.1 & 28.3 & 15.0 & 17.8 \\
\hline \multicolumn{6}{|c|}{ Nutrients and total organic carbon } \\
\hline 00623 & Ammonia + organic-N, wf, mg/L as $\mathrm{N}$ & .10 & .13 & E.07 & E .06 \\
\hline 00608 & Ammonia, wf, mg/L as $\mathrm{N}$ & $<.04$ & $<.020$ & $<.04$ & $<.020$ \\
\hline 00631 & Nitrate plus nitrite, wf, $\mathrm{mg} / \mathrm{L}$ as $\mathrm{N}$ & 7.45 & 3.00 & .23 & .25 \\
\hline 00613 & Nitrite, wf, $\mathrm{mg} / \mathrm{L}$ as $\mathrm{N}$ & $<.008$ & $<.002$ & $<.008$ & $<.002$ \\
\hline 00671 & Orthophosphate, wf, $\mathrm{mg} / \mathrm{L}$ as $\mathrm{P}$ & $<.02$ & E.006 & $<.16$ & $<.06$ \\
\hline 00680 & Total organic carbon, wu, mg/L & 1.2 & 2.2 & 1.4 & 1.1 \\
\hline \multicolumn{6}{|c|}{ Bacteria } \\
\hline 31691 & Escherichia coli, wu, CFU per $100 \mathrm{~mL}$ & pos & $<1$ & pos & $<1$ \\
\hline 61215 & Fecal coliform, wu, CFU per $100 \mathrm{~mL}$ & 10 & $<1$ & $<5$ & $<1$ \\
\hline 31692 & Heterotrophic plate count, wu, CFU per $\mathrm{mL}$ & 87 & 233 & 9 & 6 \\
\hline 61213 & Total coliform, wu, CFU per $100 \mathrm{~mL}$ & pos & $>200$ & pos & 18 \\
\hline
\end{tabular}


Table 1-11. Concentrations of trace elements and radon-222 in groundwater samples collected in the Chemung River Basin, New York, 2003 and 2008.

[Well locations are shown in figure 1. NWIS, National Water Information System; wu, unfiltered water; wf, filtered water; $\mu \mathrm{g} / \mathrm{L}$, micrograms per liter; $\mathrm{pCi} / \mathrm{L}$, picocuries per liter; <, less than; $\mathrm{m}$, constituent was detected in the sample but was not quantified; E, estimated value — constituent was detected in the sample but with low or inconsistent recovery]

\begin{tabular}{|c|c|c|c|c|c|}
\hline \multirow{2}{*}{$\begin{array}{l}\text { U.S. Geological } \\
\text { Survey NWIS } \\
\text { parameter code }\end{array}$} & \multirow{2}{*}{ Constituent } & \multicolumn{2}{|c|}{ Well SB 1470} & \multicolumn{2}{|c|}{ Well CM 628} \\
\hline & & 2003 & 2008 & 2003 & 2008 \\
\hline \multicolumn{6}{|c|}{ Trace elements } \\
\hline 01105 & Aluminum, wu, $\mu \mathrm{g} / \mathrm{L}$ & 4 & 25 & 4 & $<6$ \\
\hline 01007 & Barium, wu, $\mu \mathrm{g} / \mathrm{L}$ & 77 & 77.8 & 129 & 152 \\
\hline 01020 & Boron, wf, $\mu \mathrm{g} / \mathrm{L}$ & 30 & 29 & 20 & 16 \\
\hline 01034 & Chromium, wu, $\mu \mathrm{g} / \mathrm{L}$ & $<0.8$ & $<0.40$ & $<0.8$ & $<0.40$ \\
\hline 01037 & Cobalt, wu, $\mu \mathrm{g} / \mathrm{L}$ & $\mathrm{m}$ & E.08 & $\mathrm{m}$ & $<.10$ \\
\hline 01042 & Copper, wu, $\mu \mathrm{g} / \mathrm{L}$ & 18.6 & 10.4 & 1.3 & $<4.0$ \\
\hline 01046 & Iron, wf, $\mu \mathrm{g} / \mathrm{L}$ & $<8$ & E 3 & $<8$ & $<4$ \\
\hline 01045 & Iron, wu, $\mu \mathrm{g} / \mathrm{L}$ & $\mathrm{m}$ & 40 & $<6$ & $<14$ \\
\hline 01051 & Lead, wu, $\mu \mathrm{g} / \mathrm{L}$ & $\mathrm{m}$ & .50 & $\mathrm{~m}$ & .13 \\
\hline 01132 & Lithium, wu, $\mu \mathrm{g} / \mathrm{L}$ & 11.5 & 10.4 & 1.2 & 1.5 \\
\hline 01056 & Manganese, wf, $\mu \mathrm{g} / \mathrm{L}$ & 4.2 & .3 & $<.4$ & $<.2$ \\
\hline 01055 & Manganese, wu, $\mu \mathrm{g} / \mathrm{L}$ & 5 & 10.1 & $<.22$ & 1.1 \\
\hline 01062 & Molybdenum, wu, $\mu \mathrm{g} / \mathrm{L}$ & E. 2 & .1 & E.1 & .1 \\
\hline 01067 & Nickel, wu, $\mu \mathrm{g} / \mathrm{L}$ & 2 & .41 & 1 & E.17 \\
\hline 01147 & Selenium, wu, $\mu \mathrm{g} / \mathrm{L}$ & $<.5$ & $<.12$ & $<.5$ & $<.12$ \\
\hline 01082 & Strontium, wu, $\mu \mathrm{g} / \mathrm{L}$ & 273 & 227 & 95 & 110 \\
\hline 28011 & Uranium, wu, $\mu \mathrm{g} / \mathrm{L}$ & .102 & .104 & .138 & .177 \\
\hline 01092 & Zinc, wu, $\mu \mathrm{g} / \mathrm{L}$ & 3 & 6.9 & 6 & 4.6 \\
\hline \multicolumn{6}{|c|}{ Radon-222 } \\
\hline 82303 & Radon-222, wu, pCi/L & 2,580 & 1,460 & 570 & 450 \\
\hline
\end{tabular}


Table 1-12. Concentrations of pesticides in groundwater samples collected in the Chemung River Basin, New York, 2003 and 2008.

[Well locations are shown in figure 1. NWIS, National Water Information System; wf, filtered water; $\mu \mathrm{g} / \mathrm{L}$, micrograms per liter; <, less than; E, estimated value - constituent was detected in the sample but with low or inconsistent recovery]

\begin{tabular}{|c|c|c|c|c|c|}
\hline \multirow{2}{*}{$\begin{array}{l}\text { U.S. Geological Survey } \\
\text { NWIS parameter code }\end{array}$} & \multirow{2}{*}{ Constituent } & \multicolumn{2}{|c|}{ Well SB 1470} & \multicolumn{2}{|c|}{ Well CM 628} \\
\hline & & 2003 & 2008 & 2003 & 2008 \\
\hline 04040 & 2-Chloro-4-isopropylamino-6-amino-s-triazine (CIAT), wf, $\mu \mathrm{g} / \mathrm{L}$ & $<0.006$ & $<0.014$ & E 0.007 & E 0.009 \\
\hline 50009 & Alachlor ESA, wf, $\mu \mathrm{g} / \mathrm{L}$ & $<.05$ & $<.02$ & $<.05$ & $<.02$ \\
\hline 39632 & Atrazine, wf, $\mu \mathrm{g} / \mathrm{L}$ & $<.007$ & $<.040$ & .011 & Е.008 \\
\hline 61043 & Metolachlor ESA, wf, $\mu \mathrm{g} / \mathrm{L}$ & $<.05$ & $<.02$ & $<.05$ & $<.02$ \\
\hline
\end{tabular}

Table 1-13. Concentrations of volatile organic compounds in groundwater samples collected in the Chemung River Basin, New York, 2003 and 2008.

[Well locations are shown in figure 1. NWIS, National Water Information System; wu, unfiltered water; $\mu \mathrm{g} / \mathrm{L}$, micrograms per liter; $<$, less than]

\begin{tabular}{|c|c|c|c|c|c|}
\hline \multirow{2}{*}{$\begin{array}{l}\text { U.S. Geological Survey } \\
\text { NWIS parameter code }\end{array}$} & \multirow{2}{*}{ Constituent } & \multicolumn{2}{|c|}{ Well SB 1470} & \multicolumn{2}{|c|}{ Well CM 628} \\
\hline & & 2003 & 2008 & 2003 & 2008 \\
\hline 34506 & 1,1,1-Trichloroethane, wu, $\mu \mathrm{g} / \mathrm{L}$ & $<0.1$ & $<0.1$ & $<0.1$ & $<0.1$ \\
\hline 32106 & Trichloromethane, wu, $\mu \mathrm{g} / \mathrm{L}$ & $<.1$ & $<.1$ & $<.1$ & $<.1$ \\
\hline 34010 & Toluene, wu, $\mu \mathrm{g} / \mathrm{L}$ & $<.1$ & $<.1$ & $<.1$ & $<.1$ \\
\hline 39180 & Trichloroethene, wu, $\mu \mathrm{g} / \mathrm{L}$ & $<.1$ & $<.1$ & $<.1$ & $<.1$ \\
\hline 34475 & Tetrachloroethene, wu, $\mu \mathrm{g} / \mathrm{L}$ & $<.1$ & $<.1$ & $<.1$ & $<.1$ \\
\hline 78032 & Methyl tert-butyl ether (MTBE), wu, $\mu \mathrm{g} / \mathrm{L}$ & $<.2$ & $<.2$ & $<.2$ & $<.2$ \\
\hline
\end{tabular}


This page has been left blank intentionally. 
Prepared by the Pembroke Publishing Service Center

For additional information write to:

New York Water Science Center

U.S. Geological Survey

30 Brown Rd.

Ithaca, NY 14850

Information requests:

(518) 285-5602

or visit our Web site at: http://ny.water.usgs.gov 
